\title{
المسائل التي حُكِم فيها بالقرائن و الأمارات عند ابن فرحون \\ في باب الاقطة \\ جمعا ودراسة
}

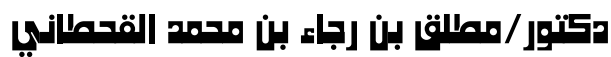

القاضي بوزارة العدل السعودية

\section{المقدمة}

الحمد لله نحمده ونستعينه ونستغفره ونتوب إليه، ونعوذ باله من شرور أنفـسنا، ومــن

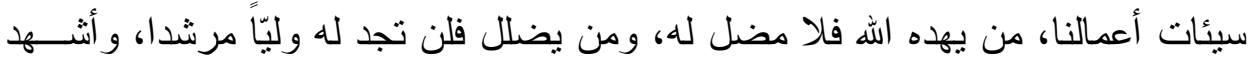

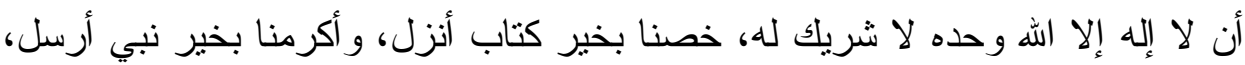

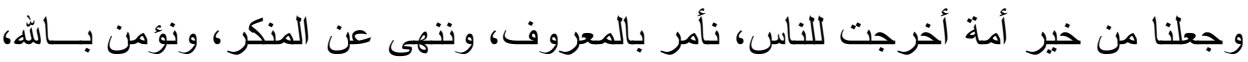
و أثثهد أن محمداً عبده ورسوله، بعثه الله تعالى بالهدى ودين الحق ليظهره على بلى الــدين

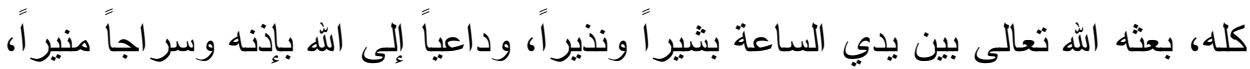

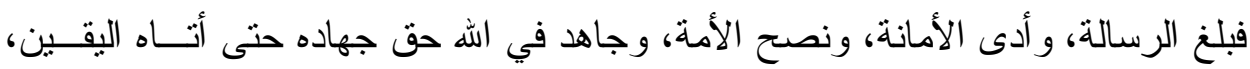

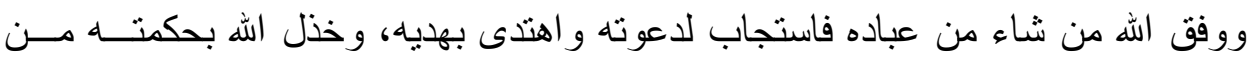

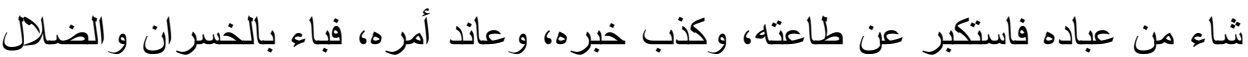
البعيد. أما بعد:

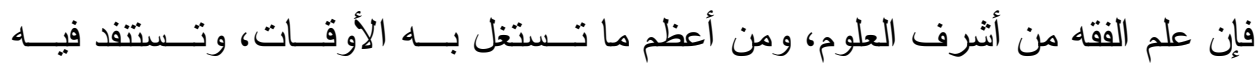

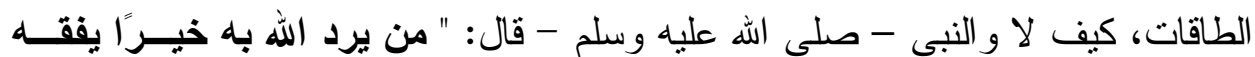

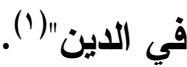

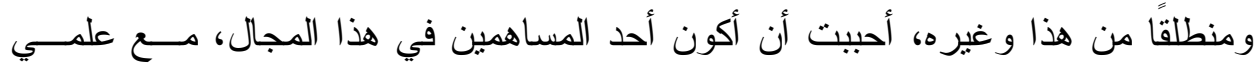
التام بضعف همتي، وقلة بضاعتي، غير أنها خطو ات مبتدئ، و عَزمَات استثار ها أنتـــاء 


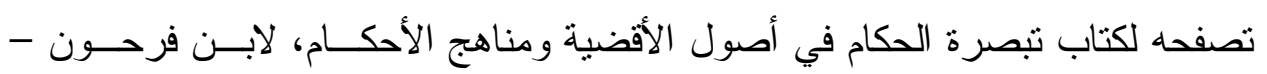

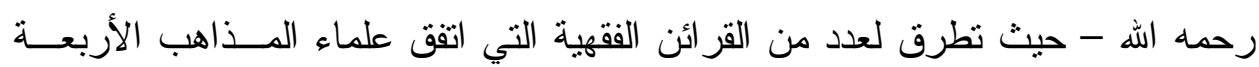

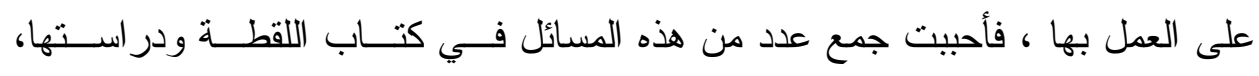
وتحقيق أقو ال المذاهب فيها، و لا يخفى على المتخصص في في الجانب القضائي ما لابــن

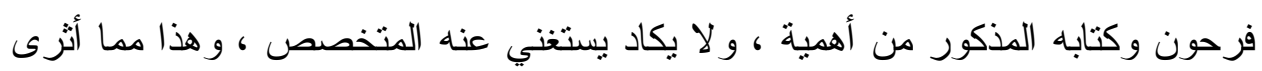

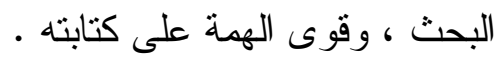

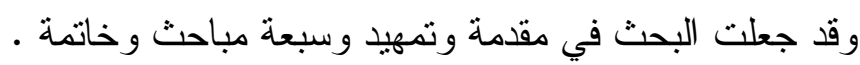

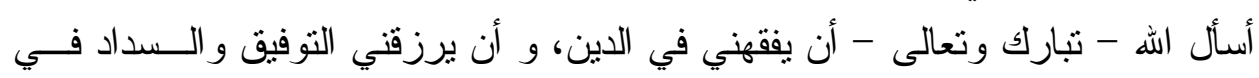
القول و العمل إنه سميع مجيب. 


\section{التمهيا \\ أنواع القر ائن وحجيتها.}

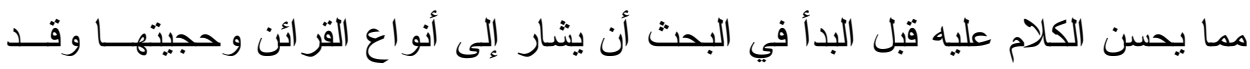
جعلتها في مطلبان : المطلب الأول: أنو اع القر ائن:

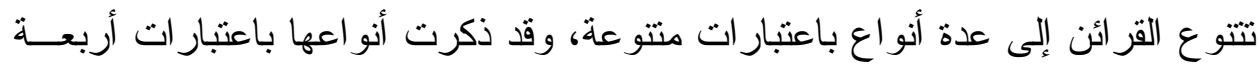

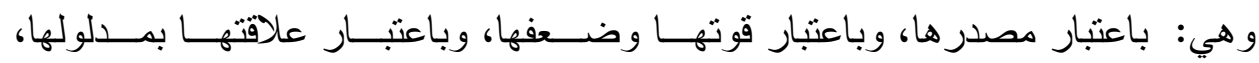
و أنو اعها في القانون، وقد ذكرت ذللك في أربعة مسائل وهي:

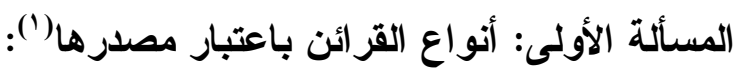

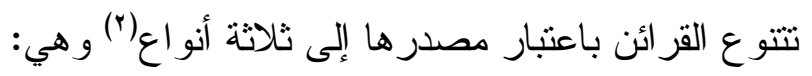
النوع الأول: القرائن النصية:

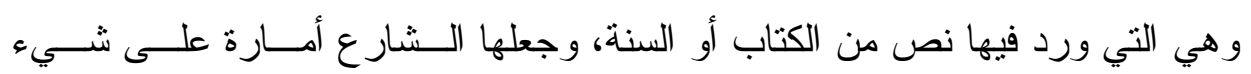

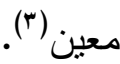

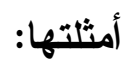

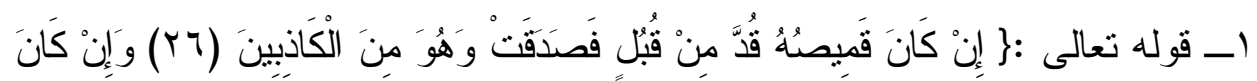

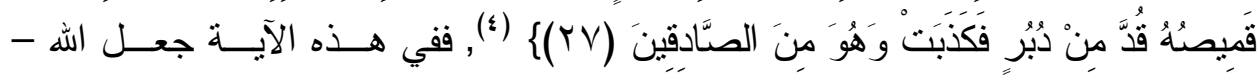

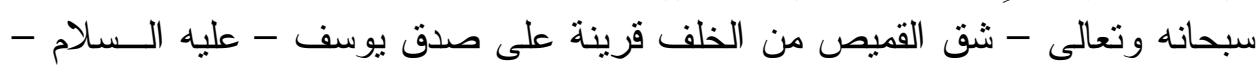

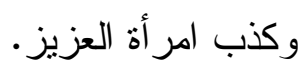

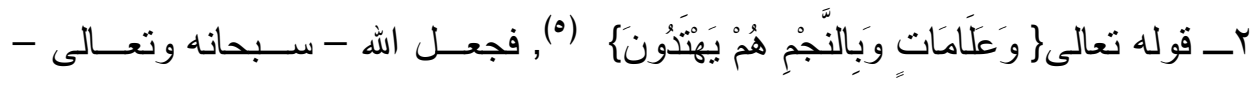

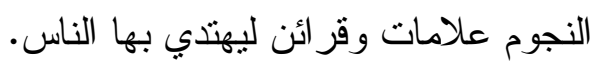

(1) ينظر : وسائل الإثبات في الثريعة الإسلامية للزحيلي صع 9 ؟، الإثبات بالقر ائن في الفقه الإســلامي لإبـــر اهيم الفـايز

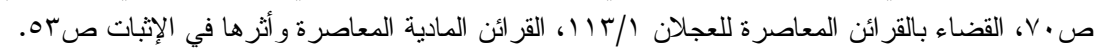

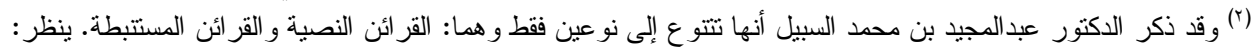

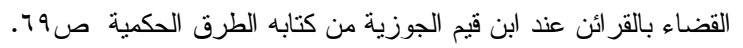

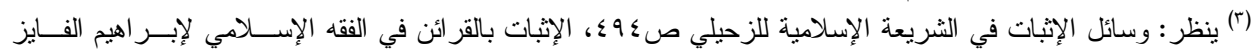

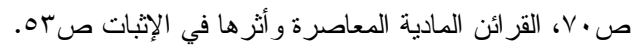

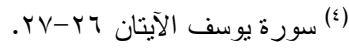

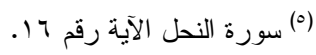




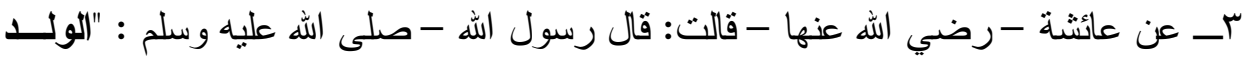

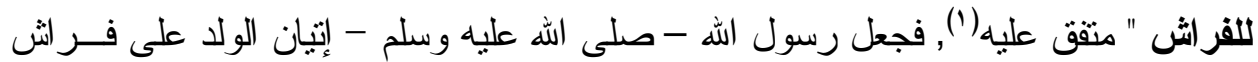
الزوجية دليل على لحوقه بأبيه. النوع الثاني: القرائن الفقهية: لائية وهي القرائن التي استتبطها الفقهاء و استخرجوها باجتهادهم، وجعلوها أدلة على أمسـور

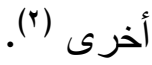
أمثثتها: اــ أن الضيف يشرب من كوز صاحب البيت، ويتكئ على وساده، ويقضي حاجته في

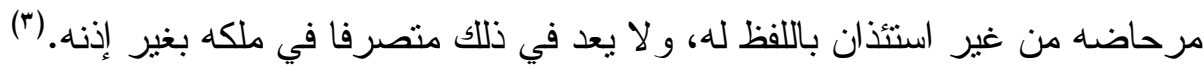

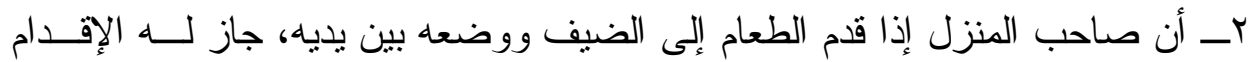

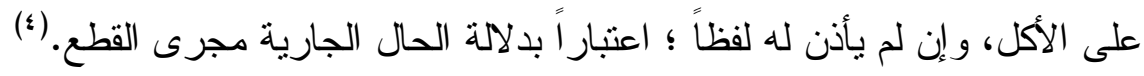
فدلت القرينة على الإذن فيما تقدم، ولم يكن هنالك لفظ من صاحن الفب المن المنزل. النوع الثالث: القرائن القضائية: و هي التي يستنبطها القاضي بفطنته وذكائه، ومن خلال سماعه دعوى المدعي، وإجابــة المدعى عليه، و الظروف المحيطة بالدعوى (•). أمثثتها: اـ ما ذكره ابن القيم - رحمه الله - بقوله: "أن اللصوص أخذوا في زمن المكتفي مالا

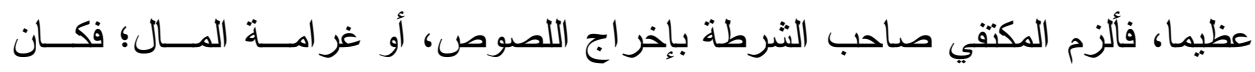

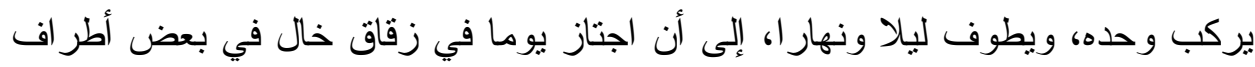

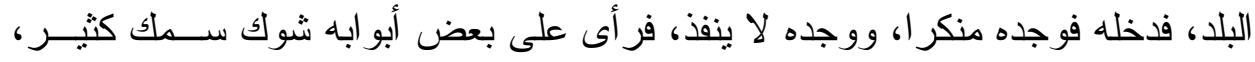

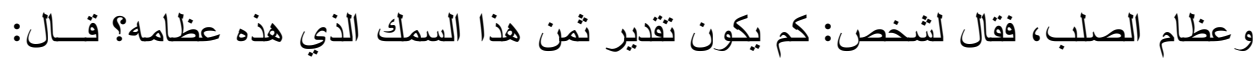

(1) رو اه البخاري في كتاب الفر ائض باب الولد للفر اش حرة كانت أو أمة برقم 9 \لاT, ومسلم في كتاب الرضاع، باب الولا

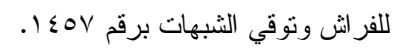

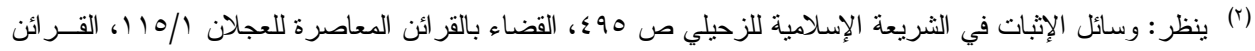

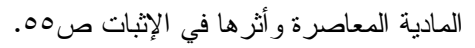

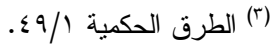

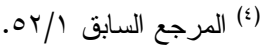

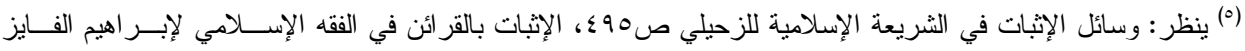

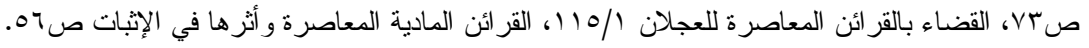


دينار ، قال: أهل الزقاق لا تحتمل أحو الهم مشتري متل هذا، لأنه زقاق بــين الاخــتال

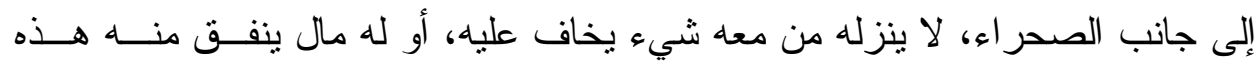

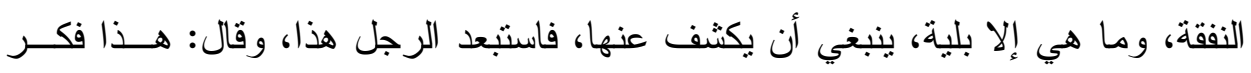

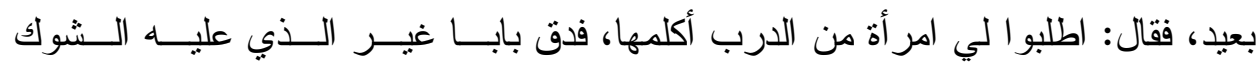

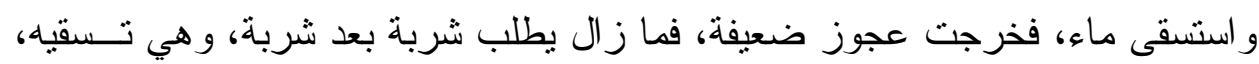

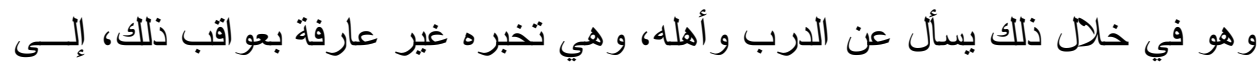

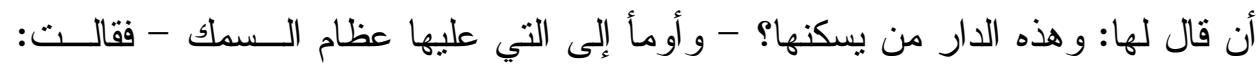

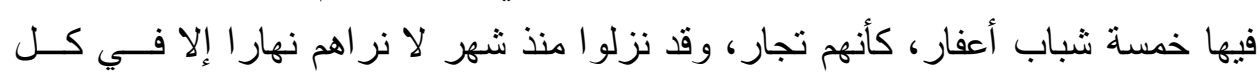

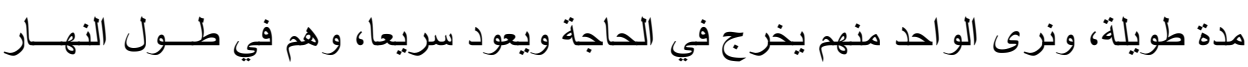

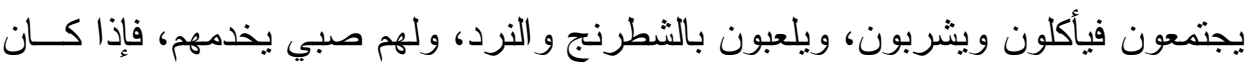

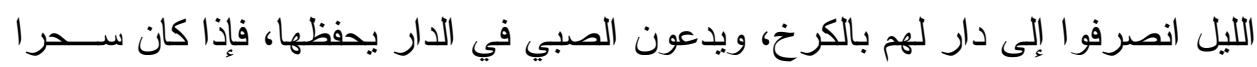

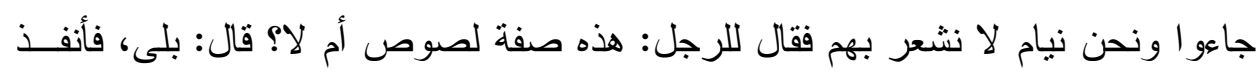

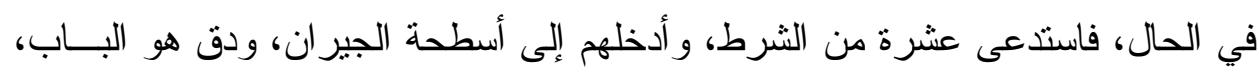

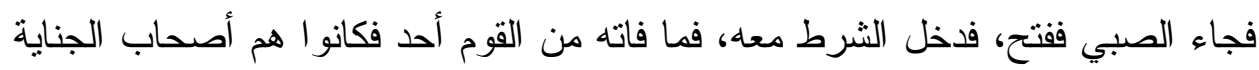

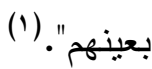

فهنا قام صاحب الثرطة باستتباط القرينة من الظروف المحيطة و الملابسات.

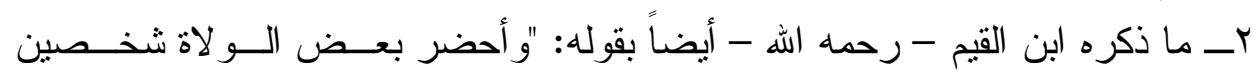

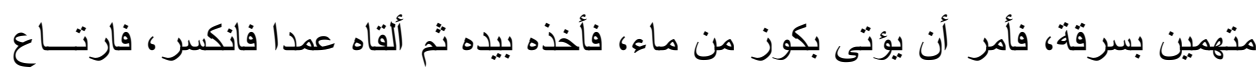

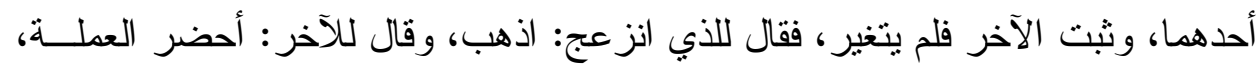

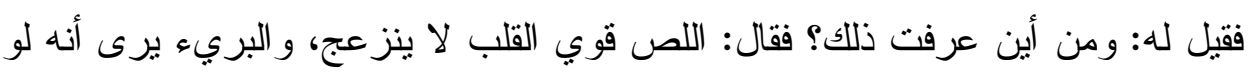

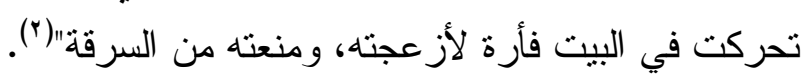

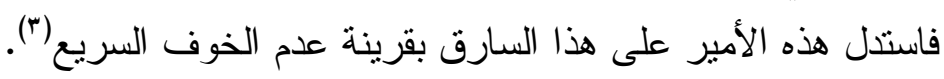

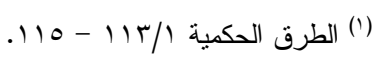

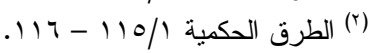

(r) وما ذكره من هذه القرينة لا يو افق فيها على اطلاقها، فإنها قد تصدق على من نكررت منه السرقة كثير ا حتى تقوى قلبه

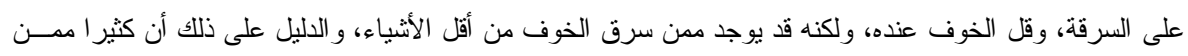

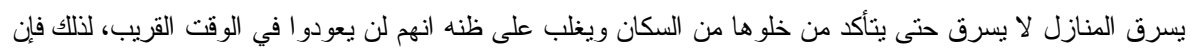

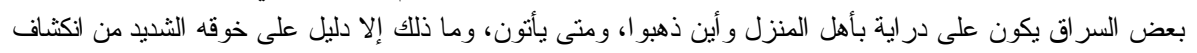


المسألة الثانية: أنواع القزائن باعتبار قوتها وضعفها ('):

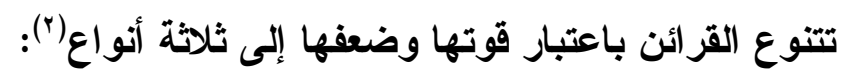
النوع الأول: القزائن القاطعة:

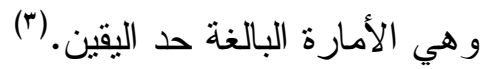
أمثلتها: اــ عن ابن عمر - رضي الله عنهما - أن رسول الله - صلى الله عليه وسلم - قاتـلـ

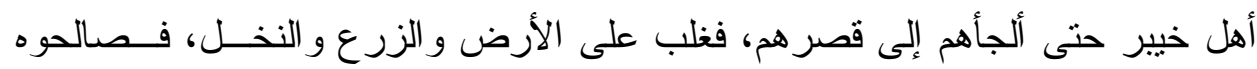

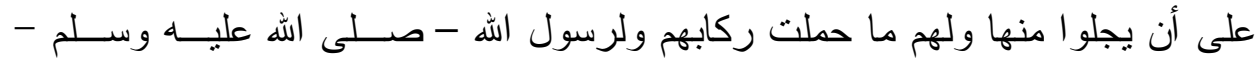

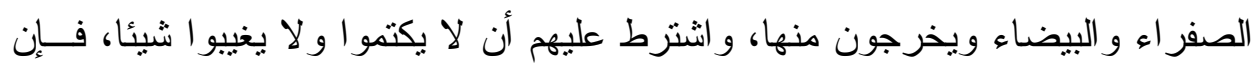

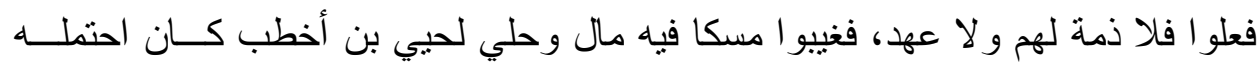

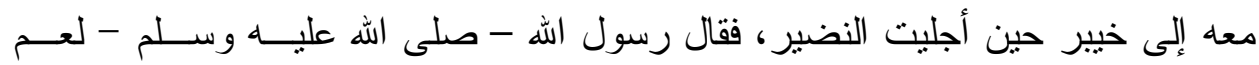
حيي: " ما فعل مسك حيي الأي جاء به من النضير؟ " فقال: أذهبته النفقات و الحروب.

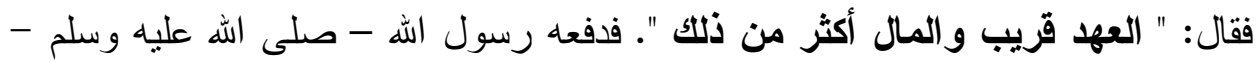

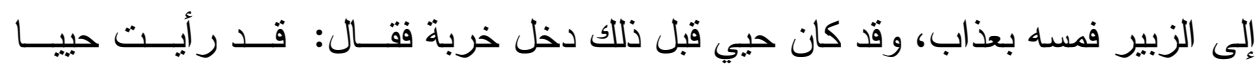

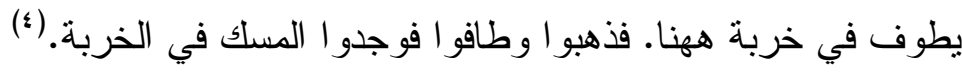

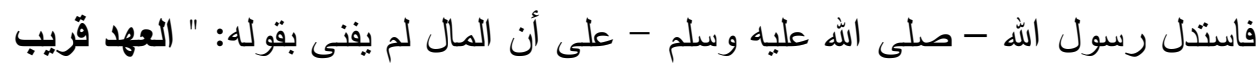
و المال أكثر من ذلك " وهذا عمل من رسول الله - صلى الله عليه وسلم - بهذه القرينة وهي تعتبر قرينة قاطعة.

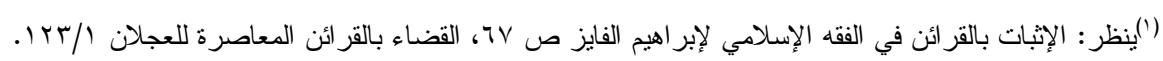

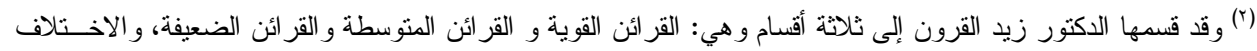

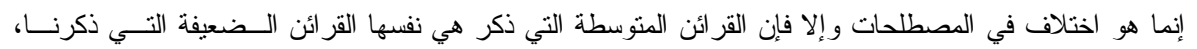

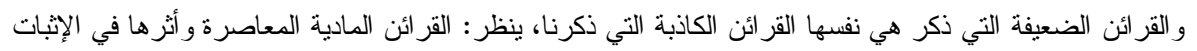

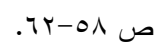

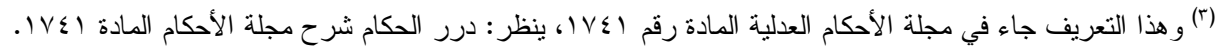
(؛) أخرجه ابن حبان في صحيحه في كتاب المز ارعة، برقم

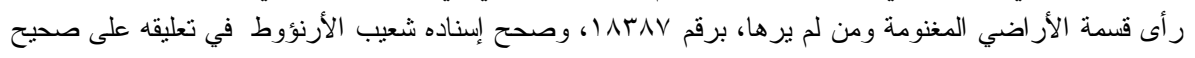




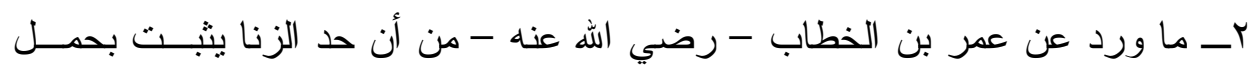

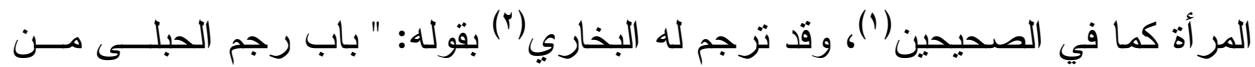

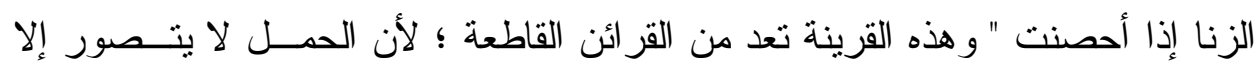
بجماع. (") النوع الثاني: القرائن الضعيفة: وهي القرائن التي تقبل إثبات عكسها، وتكون دليلا مرجحا لما معها، ومؤكدة له (؛). مثالها:

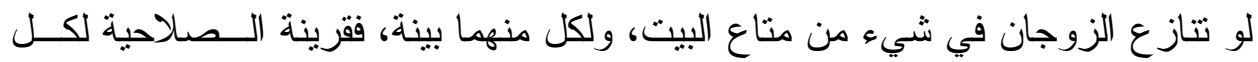

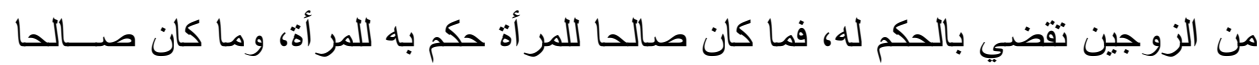

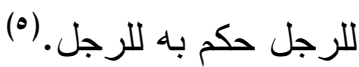

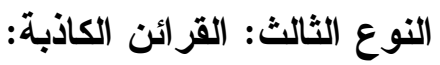

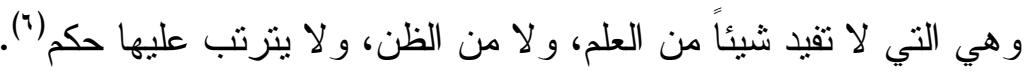
أمثثتها:

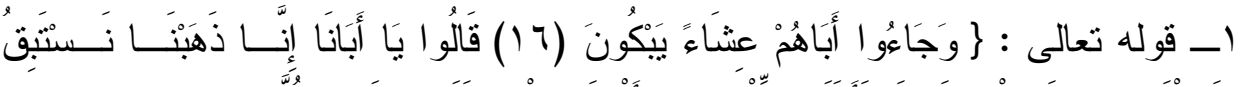

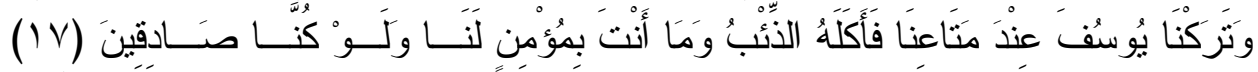

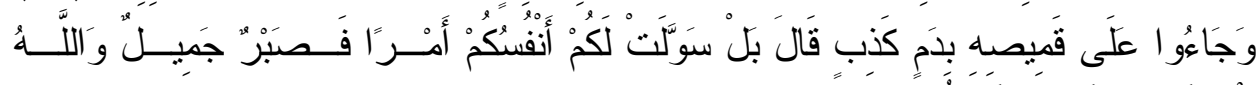

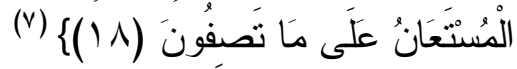

(') جاء في حديث ابن عباس - رضي الله عنهما - الطويل ونص الحاجة منه قول عمر بن الخطاب - رضي الله عنــهـ --:

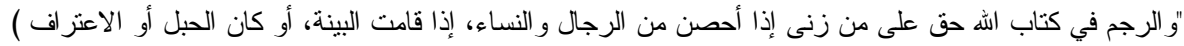

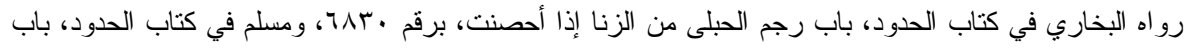

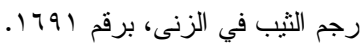

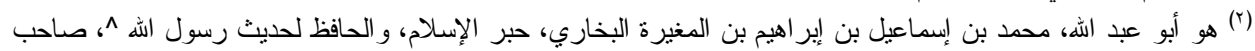

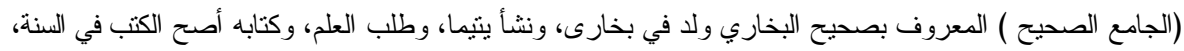

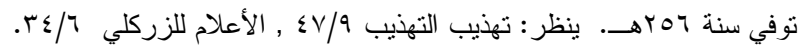

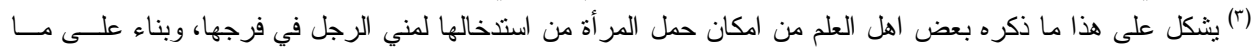

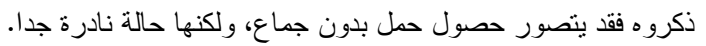

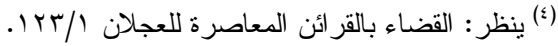

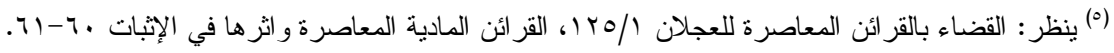

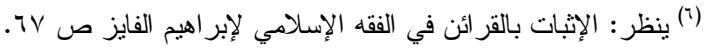

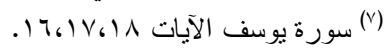




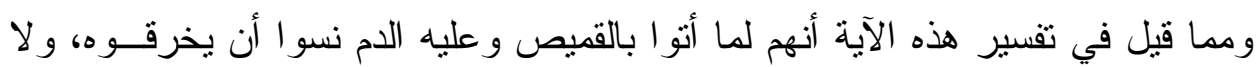

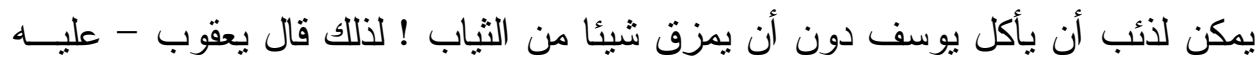

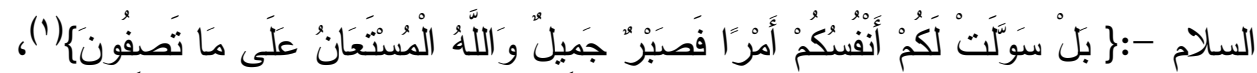

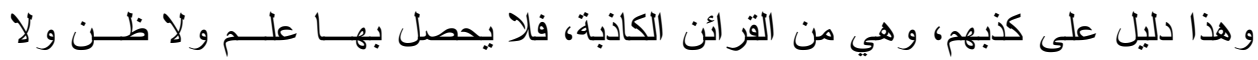
يترتب عليها حكم.

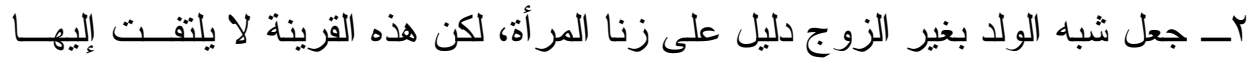

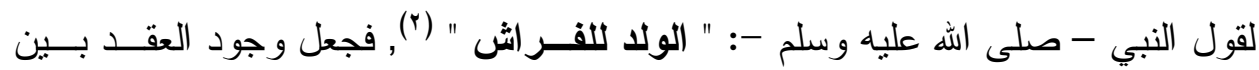

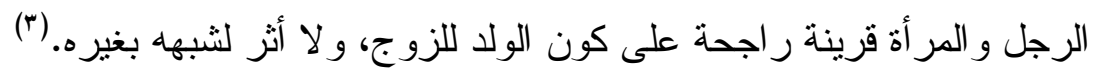

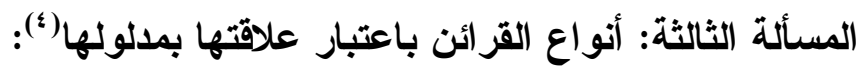
تتتوع القرائن باعتبار علاقتها بمدلولها إلى نوعين: النوع الأول: القزائن العقلية: هي التي تكون النسبة أو العلاقة بينها وبين ما تدل عليه ثابتة مستقرة، و التي يقوم العقل باستتناجها في جميع الظروف و الأحو ال (•). أمثلتها: كوجود جرح في جسم المجني عليه ؛ فإنه قرينة على استعمال آلة حادة فــي الجنايــة، وكوجود رماد فإنه دليل على سبق وجود النار (").

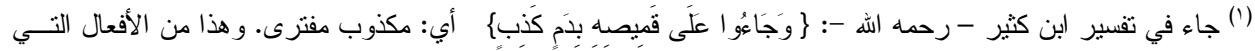

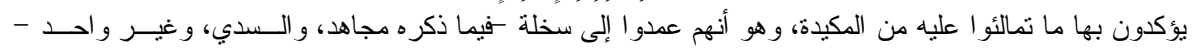

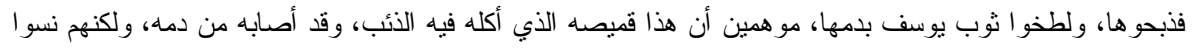

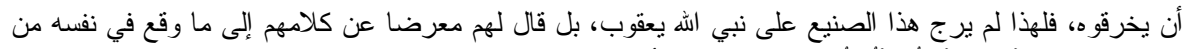

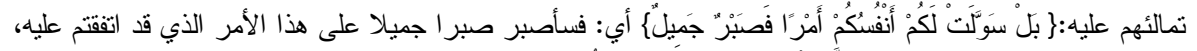

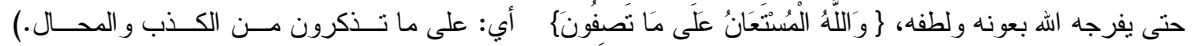

$$
. \varepsilon 9 \Lambda-\varepsilon 9 \vee / \varepsilon
$$

(") (") نقدم تخريجه.

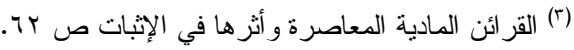

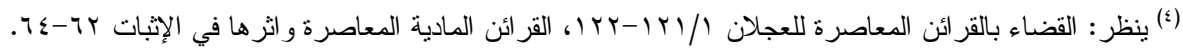

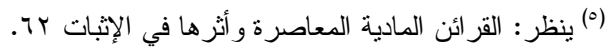

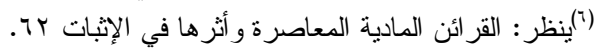


النوع الثاني: القرائن العرفية:

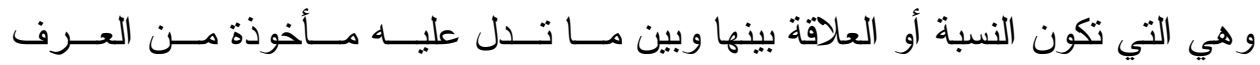
و العادة(') و (1) أمثلتها:

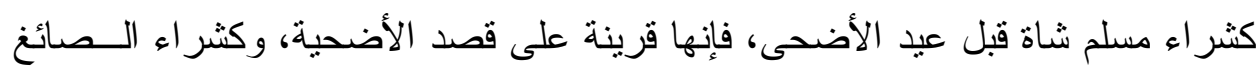

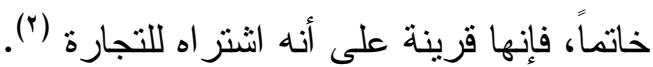

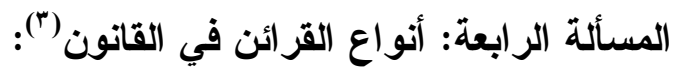
تتنوع القر ائن في القانون إلى نو عين: النوع الأول: القرائن القانونية: و هي التي يستتبطها المقنن الوضعي مما بغلب وقوعن الوفه من الحالات، فيبني عليه قاعـدة عامة ينص عليها (؛). و القرائن القانونية نوعان: النوع الأول: قرائن قانونية بسيطة:

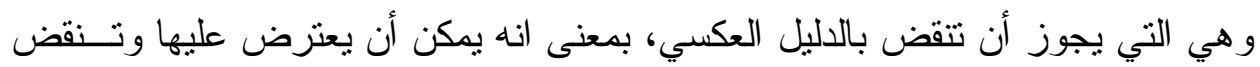
دلالتها (0). مثنالها: اعتبار تخلف الثناهد عن الحضور بعد إعلانه بالتكليف بالحضور قرينة علــى خطئـهـ، يمكن إثبات عكسها إذا حضر بعد ذلك وتقدم للمحكمة بعذر مقبول (َ). النوع الثاني: قرائن قانونية قاطعة:

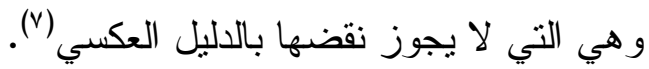

$$
\text { (1) (1) ينظر المرجع السابق. }
$$

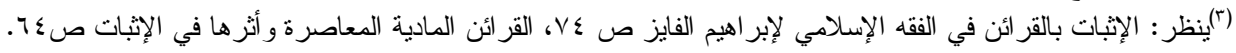

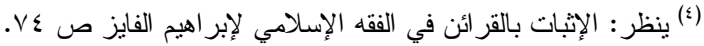

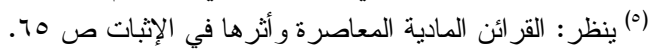
(7) (1) ينظر المرجع السابق.

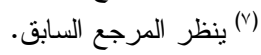


اعتبار عدم بلوغ سن السابعة قرينة على انعدام التمبيز ، ومن ثم فــلا يمكـن مـسـاءلته

جنائياً. (1)

النوع الثاني: - من أنواع القرائن في القانون - القرائن القضائية:

و هي النتائج التي يستتبطها القاضي من و اقعة معلومة ؛ لمعرفة و اقعة مجهولة (؟). مثالها:

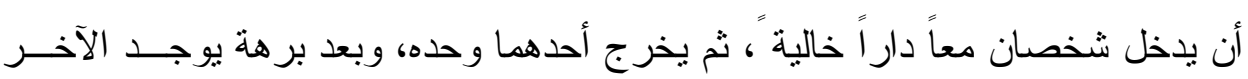

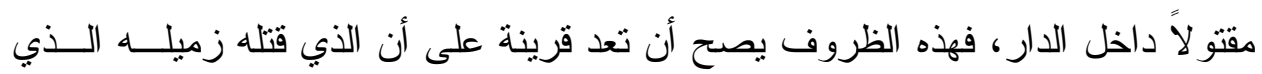
دخل معه الدار (آ).

(') ذكر هذا المثال في كتاب القر ائن المادية المعاصرة، وذكر أنه مرجعه في ذلك المادة الثالثة من القانون المصري رقم اب القاب

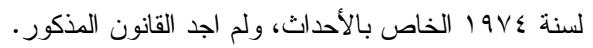

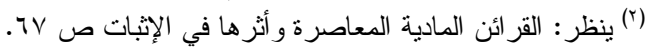
(r) 


\section{المبحث الأول}

جواز أخذ الساقط القليل لكونه مما لا يتبعه الإسسان نفسه.

\section{وفيه مطلبان:}

المطلب الأول: صورة المسألة. المطلب الثاني: أقوال أهل العلم في المسألة. يحسن فبل الكلام في هذه المسألة أن اقوم بتعريف اللقطة في اللغة و الاصطلاح:

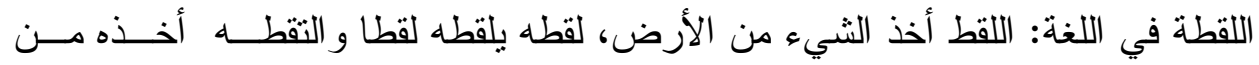

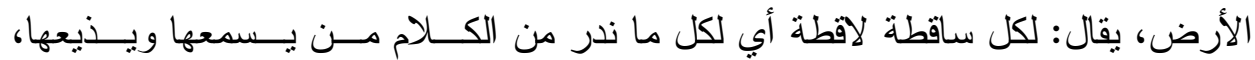

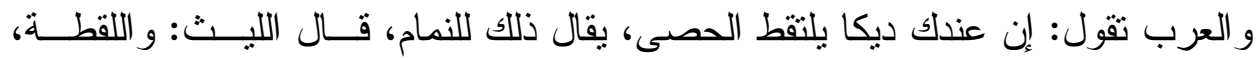

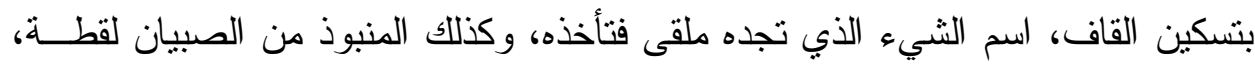
وأما اللقطة بفتح القاف، فهو الرجل اللقاط يتبع اللقطات يلتقطها. (1)

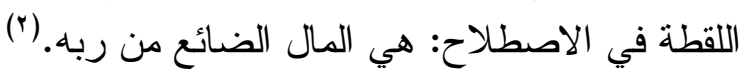
المطلب الأول: صورة المسألة: ذكر ابن فرحون - رحمه الله - هذه المسألة في الباب السبعين من الجزء التـاني مــن التهن

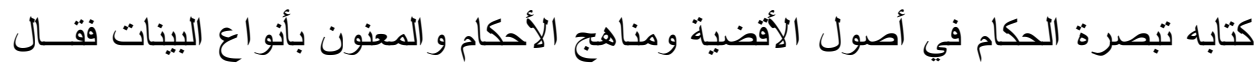

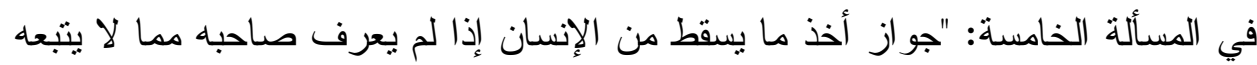

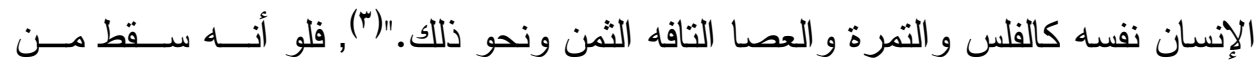

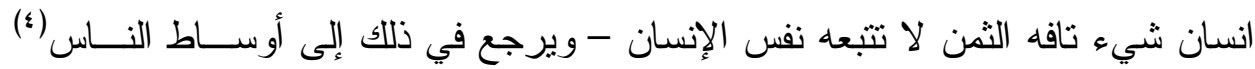

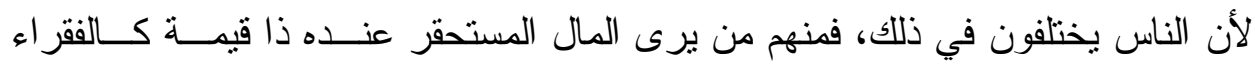

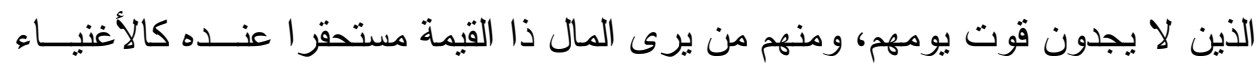

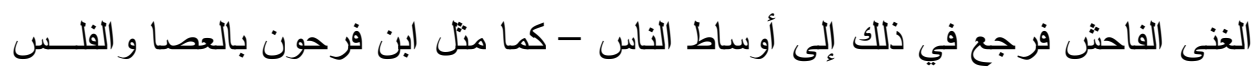

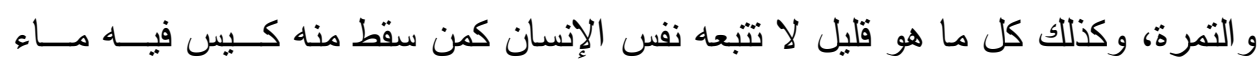

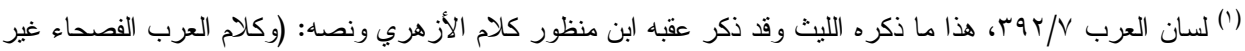

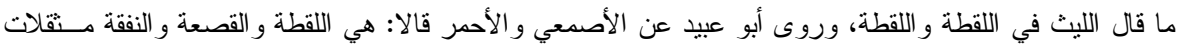

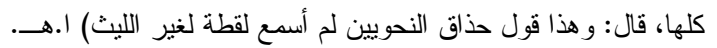


قليل، أو فيه خبزة أو غبرها مما هو قليل، فإنها إذا سقطت من الإنسان لا يكلف نفـسه

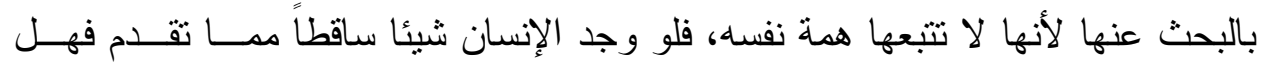

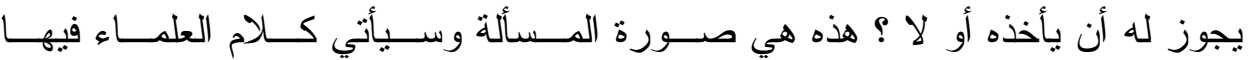
- بإذن الله - -

المطلب الثاني: أقوال أهل العلم في المسألة:

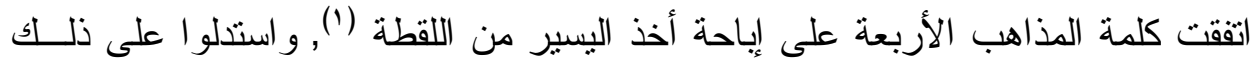

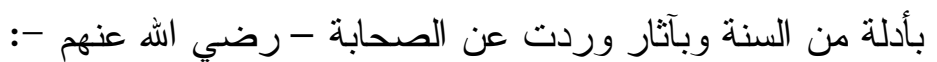
الأدلة من السنة:

1 - عن أنس - رضي الله عنه- قال: مر النبي - صلى الله عليه وسلم - بتمــرة فــي

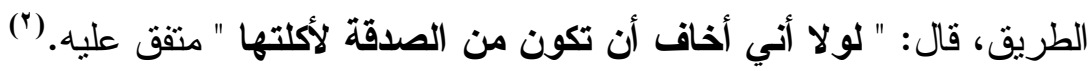

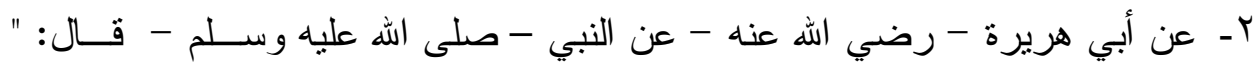
إني لأققلب إلى أهلي، فأجد التمرة ساقطة على فراشي، فأرفعها لآكلها، ثم أخشى ألى

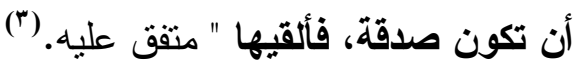
وجه الالالة من الحديثين:

أن رسول الله - صلى الله عليه وسلم - هم بأكل التمرة لولا أنه خثي أن تكون صدقة،

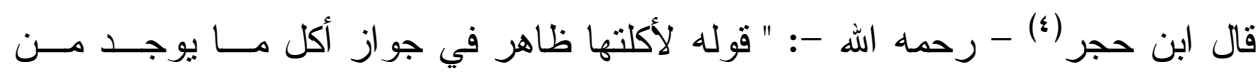

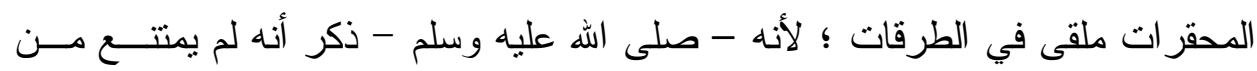

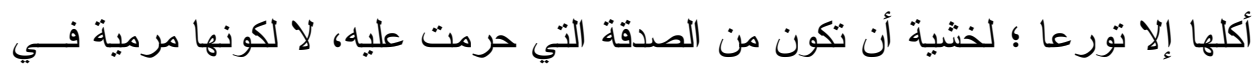

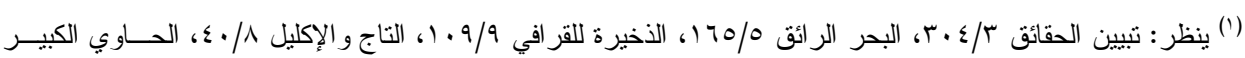

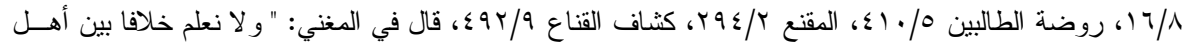

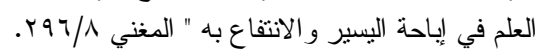

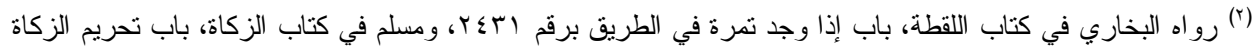

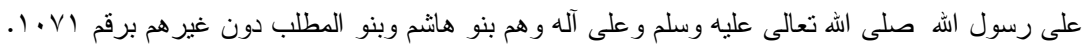

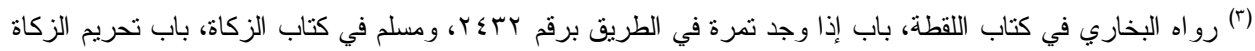

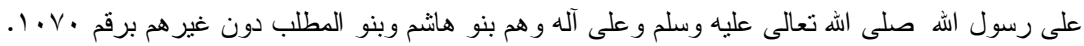

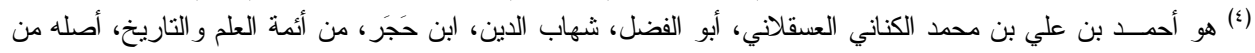

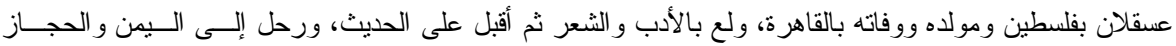

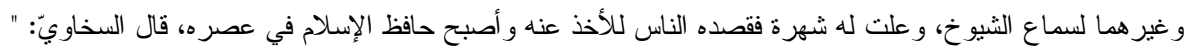

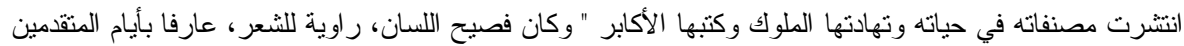

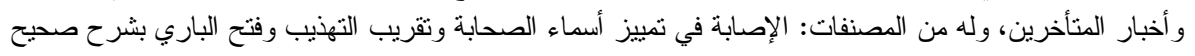

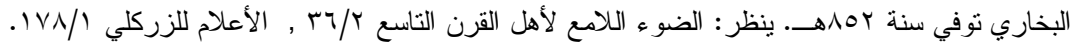


الطريق فقط، وقد أوضح ذلك قوله في حديث أبي هريرة - ثاني حـديثي البــاب - :

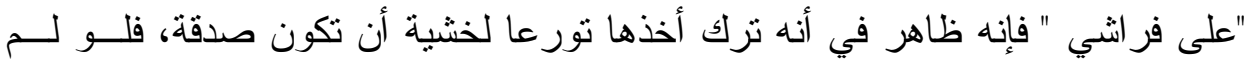

(1) بخش ذلك لأكلها". الآثار الواردة عن الصحابة: الصابة

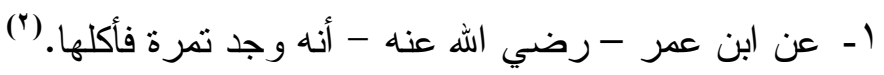
وجه الالالة من الأثر: أن عمر:

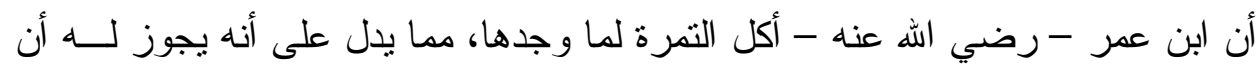

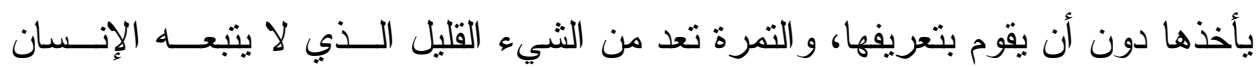
نفسه.

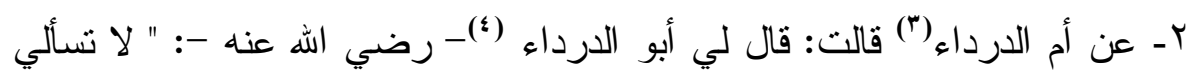

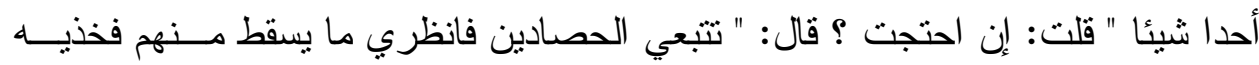

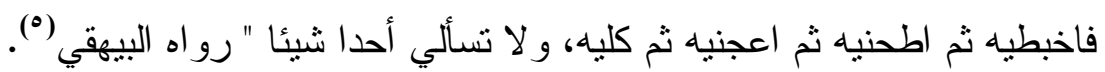

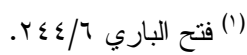

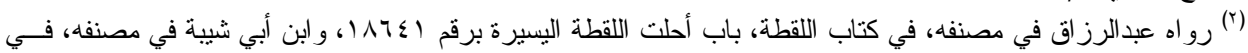

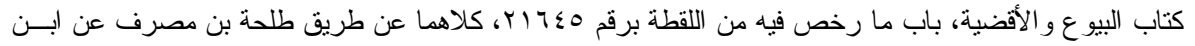

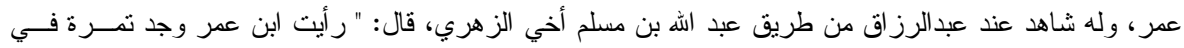

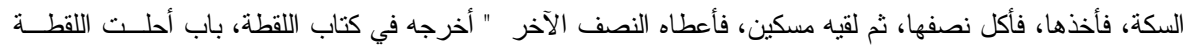

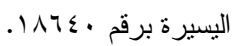

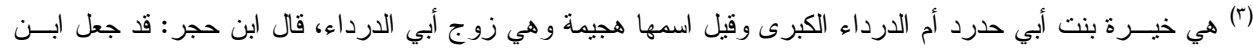

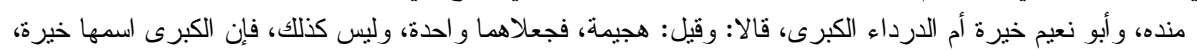

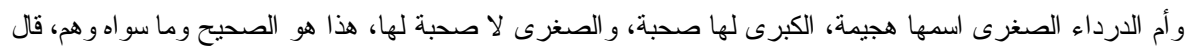

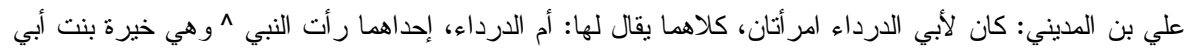

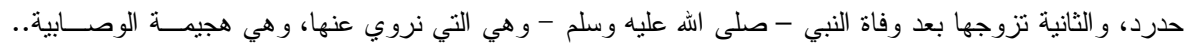

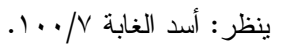

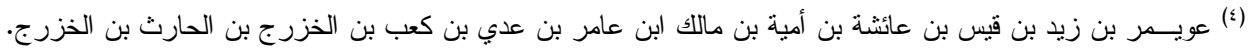

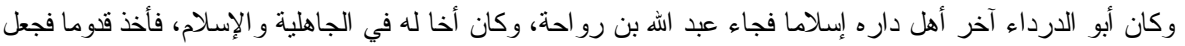

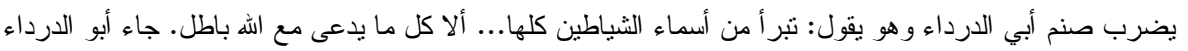

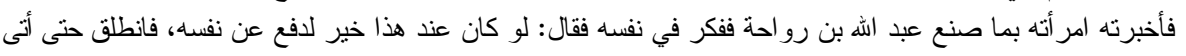

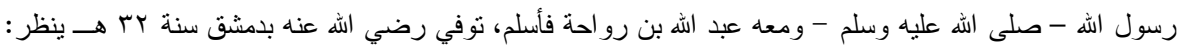

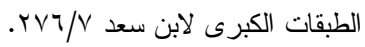

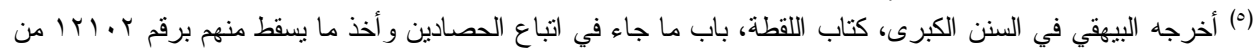

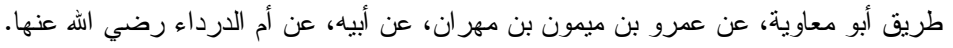




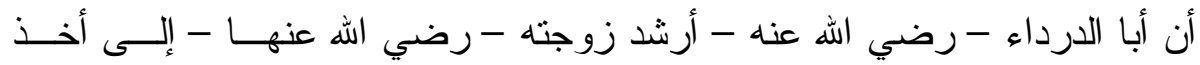

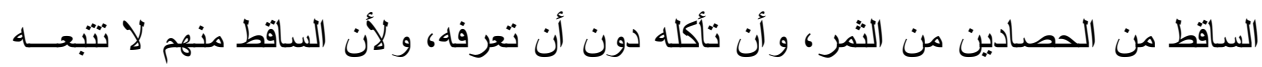
أنفسهم، وسيأتي لها مزيد تحرير في المبحث الثالث من هذه الفصل. 


\section{المبحث الثاني}

\section{جواز أخذ ما يبقى في الحوائط وغيرها بعد انتقال أهله لتخليته وتسبيبه.}

وفيه مطلبان:

المطلب الأول: صورة المسألة. المطلب الثاني: أقوال أهل العلم في المسألة. المطلب الأول: صورة المسألة:

ذكر ابن فرحون - رحمه الله - هذه المسألة في الباب السبعين من الجزء الثـاني مــن التهن

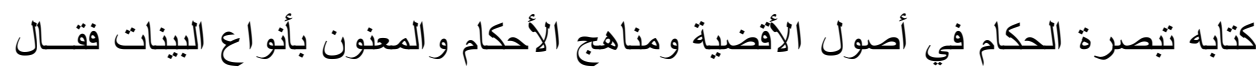

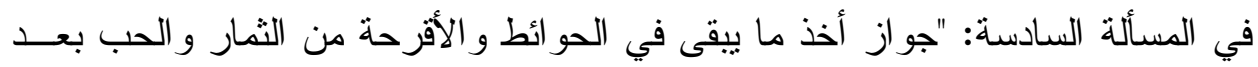

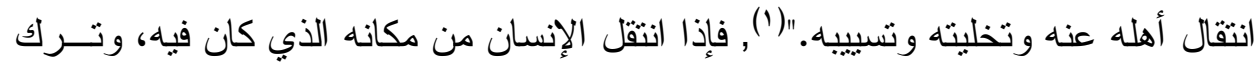

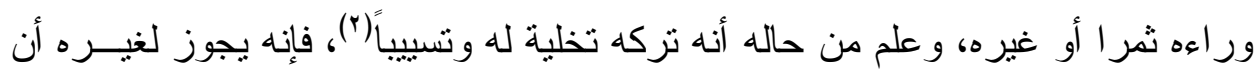

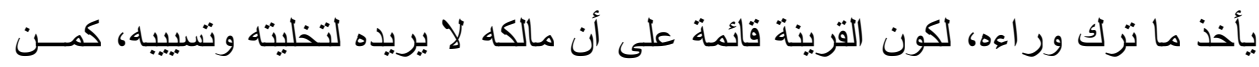

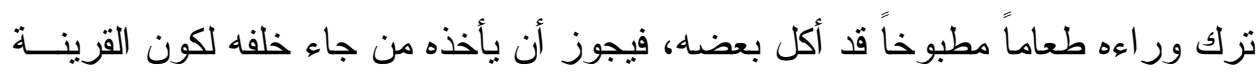
دلة على أنه لا يريد هذا الطعام أمطام. المطلب الثاني: أقوال أهل العلم في الماند المسألة:

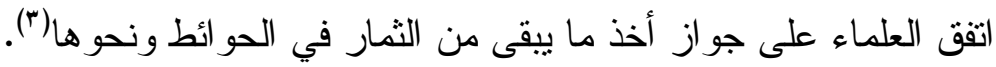
الأدلة على المسألة:

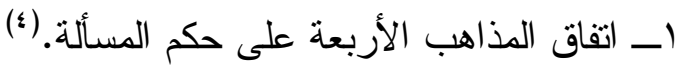

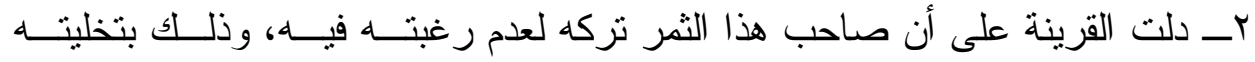
وتسبييه.

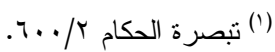

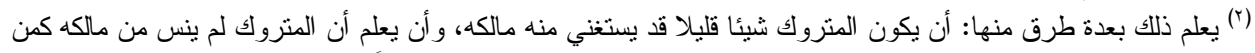

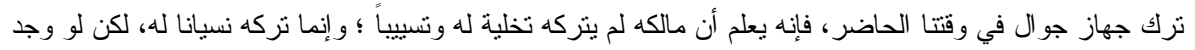

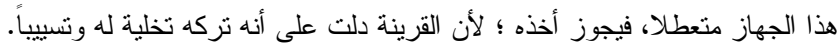

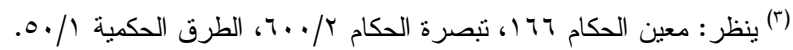

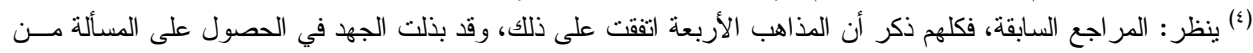
المصادر الأصلية في الدذاهب الأربعة، ولكني لم أجدها في مظانها. 
مسألة:

يلحق بالثمر و الحب أي نوع مما يجوز تملكه قد تركه صاحبه وخلاه وسيبه لغير رغبة

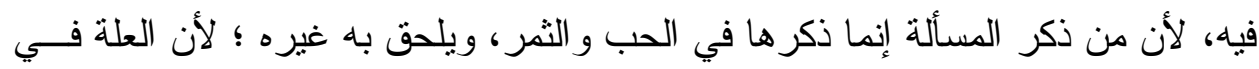

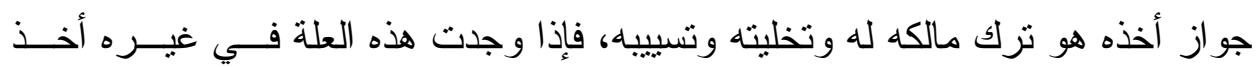
(1) حكم جو 


\section{المبحث الثالث}

جواز أخذ الساقط من الحب عند الحصاد لكون مالكه لا يعتني بلقطه.

وفيه مطلبان:

المطلب الأول: صورة المسألة.

المطلب الثاني: أقوال أهل العلم في المسألة. المطلب الأول: صورة المسألة:

ذكر ابن فرحون - رحمه الله - هذه المسألة في الباب السبعين من الجزء الثـاني مــن التهن

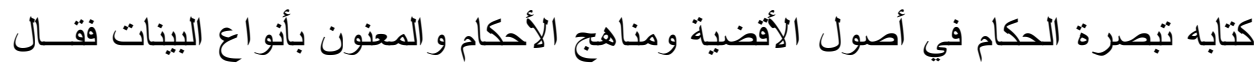

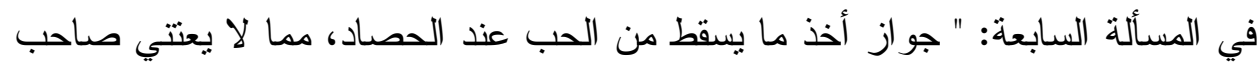

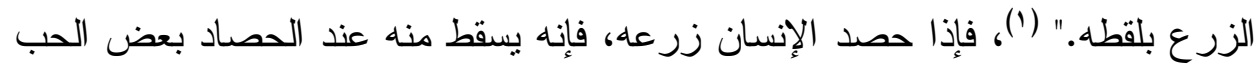
وقد جرت عادة المزارعين أنهم لا يهتمون بما يسقط عند الحصاد من الحب القليل، فإذا زئا سقط منه شيء فإنه يجوز التقاطه لكون مالكه لا بعتني بلقطه. المطلب الثاني: أقوال أهل العلم في المسألة:

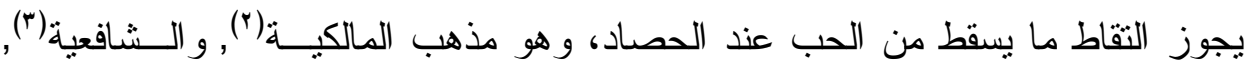
و الحنابلة(؛), ونقل بعضهم اتفاق المذاهب الأربعة على القول بهاه(ه). الأدلة على المسألة:

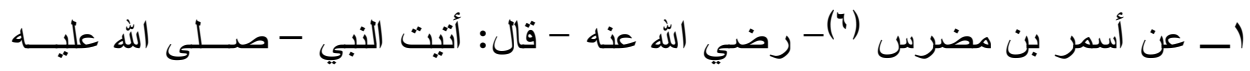

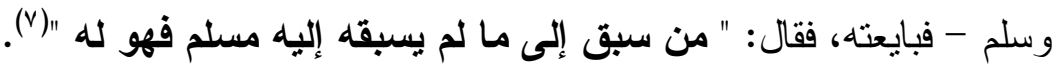

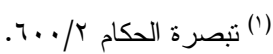

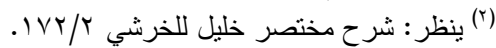

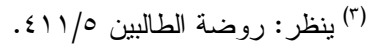

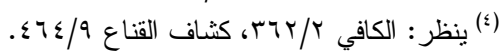

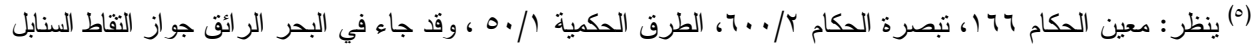
$170 \%$

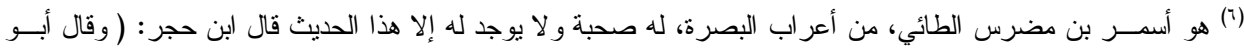

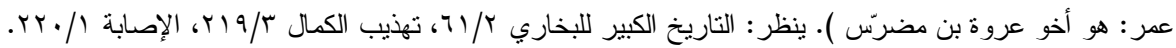

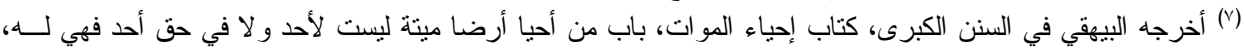

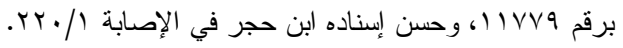




\section{وجه الالالة من الحديث:}

دل الحديث على أن من سبق إلى ما لم يسبقه إليه أحد فهو أحق به، فمن سبق إلى مـــا

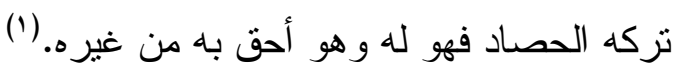

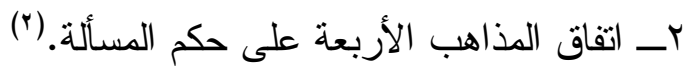

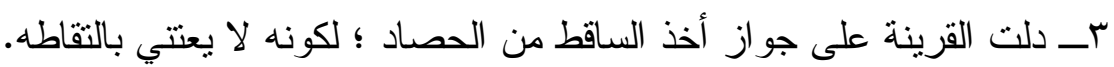

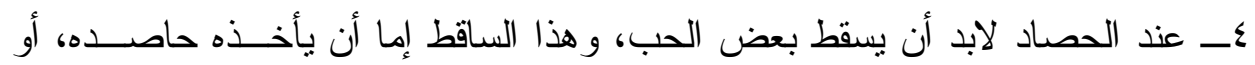

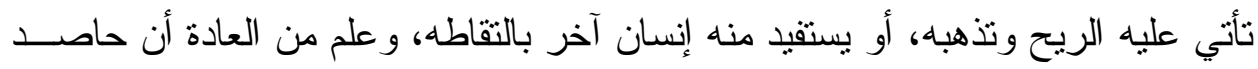

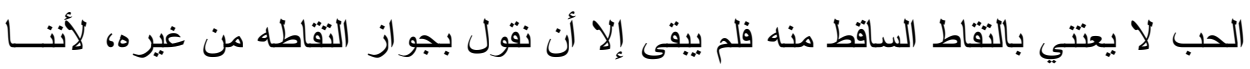
لو لم نقل به لحصل بذلك ذهاب للمال ومضيعة له لأن الريح تأتي لهذا الحب وتذهبه. 


$$
\text { المبحث الر ابع }
$$

جو از أخذ ما نبذه الناس للرغبة عنه.

\section{وفيه مطلبان:}

المطلب الأول: صورة المسألة. المطلب الثاني: أقوال أهل العلم في المسألة. المطلب الأول: صورة المسألة:

ذكر ابن فرحون - رحمه الله - هذه المسألة في الباب السبعين من الجزء الثـاني مــن التهن

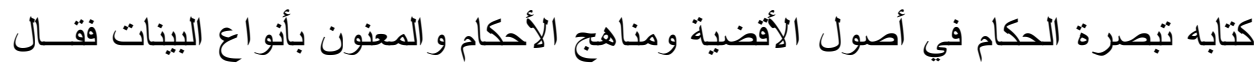

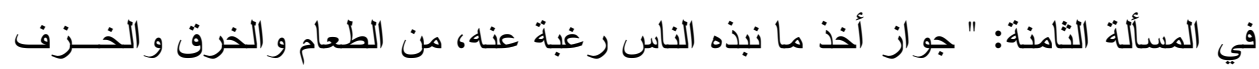

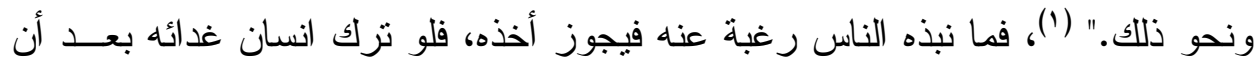

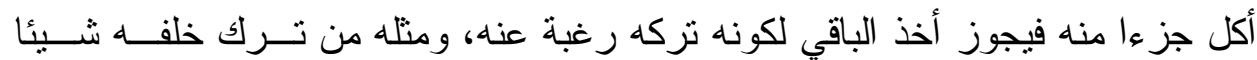
ظهر من حاله عدم رغبته به ، إلى غير ذللك من الأمتلة. المطلب الثاني: أقوال أهل العلم في المسألة:

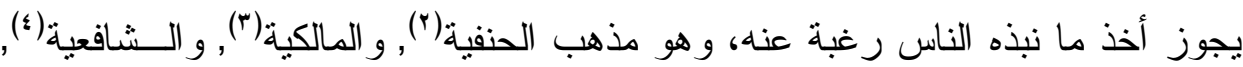

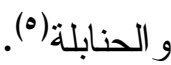

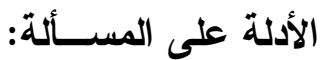

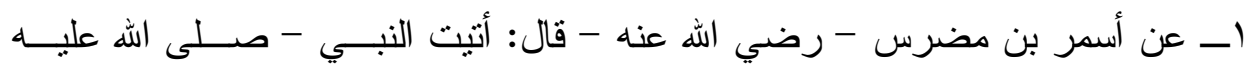
وسلم - فبايعته، فقال: " من سبق إلى ما لم يسبقه إليه مسلم فهو له "اله "("). وجه الالالة من الحديث:

دل الحديث على أن من سبق إلى ما لم يسبقه إليه أحد فهو أحق به، فمن سبق إلى مـــا

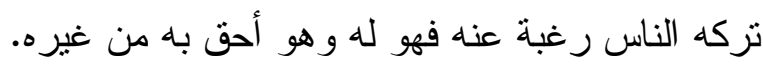


r-ـ الأصل فيما يملكه الناس الحظر، فلا يجوز لأحد أن يأخذ مال غيره بغير إذنه، فإذا

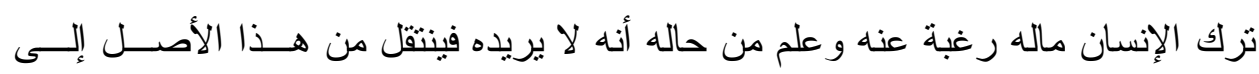

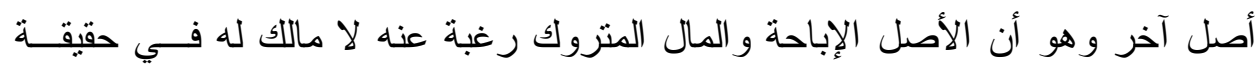
الأمر فيجوز أخذه.

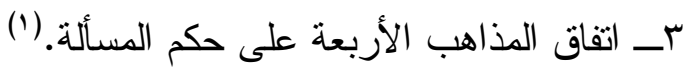

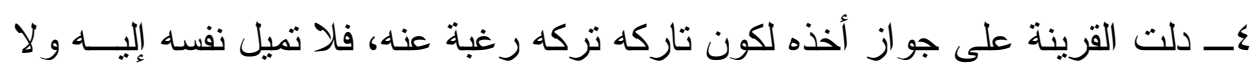
تشتهيه. 


\section{المبحث الخامس}

حكم الركاز حكم اللقطة إذا كان عليه علامة المسلمين.

وفيه مطلبان:

المطلب الأول: صورة المسألة.

المطلب الثاني: أقوال أهل العلم في المسألة.

يحسن التنبيه قبل الكلام في المسألة على بيان المقصود بالرئ الركاز :

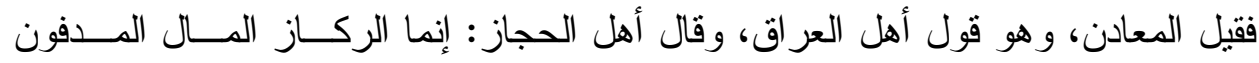

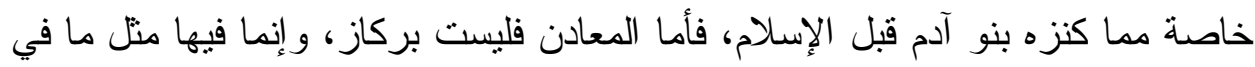

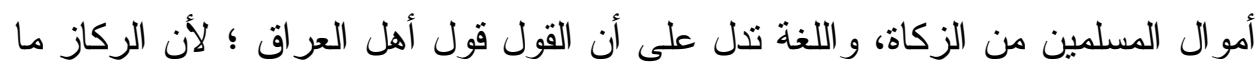

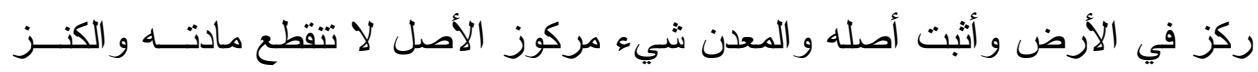

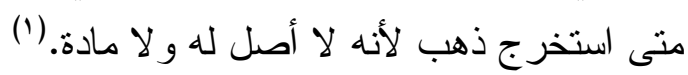

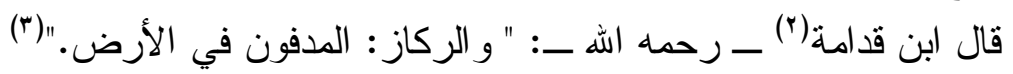

المطلب الأول: صورة المسألة:

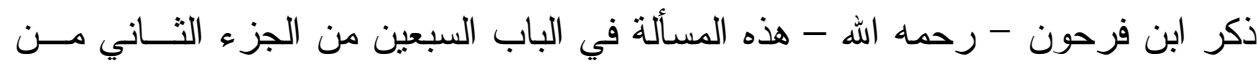

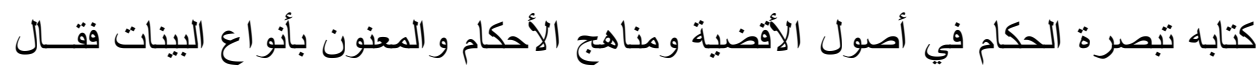

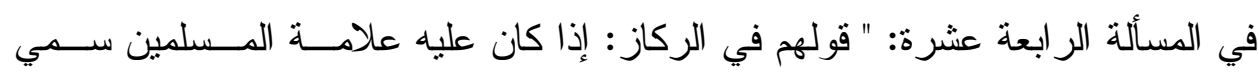

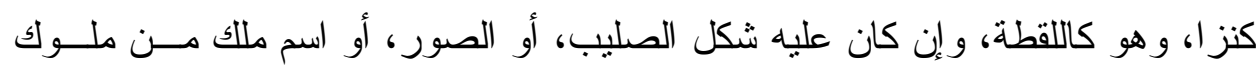

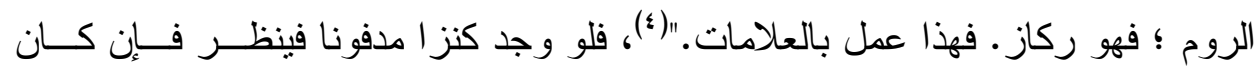

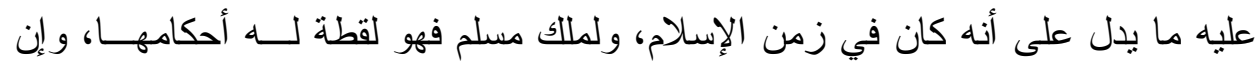

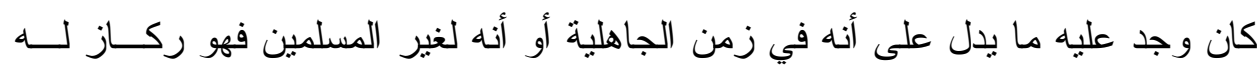

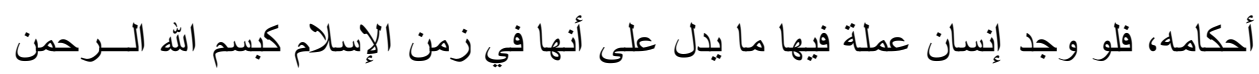

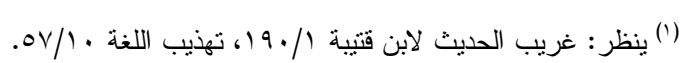

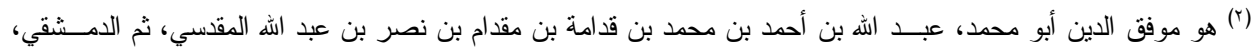

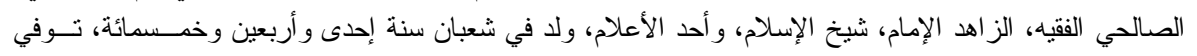

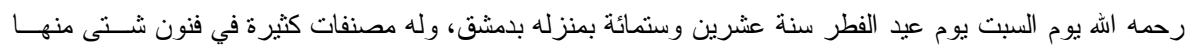

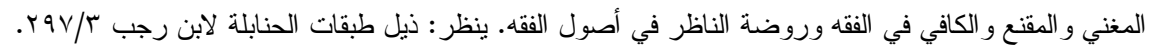
Trt

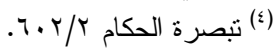


الرحيم فهي لقطة، وإن وجد عملة عليها ما يدل على أنهـــا لغيـر المـسلمين كعلامــة

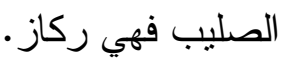
المطلب الثاني: أقوال أهل العلم في المسألة:

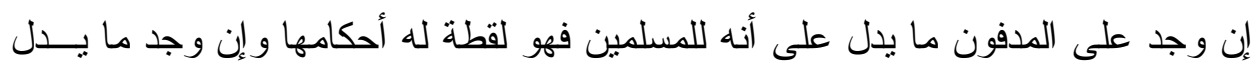

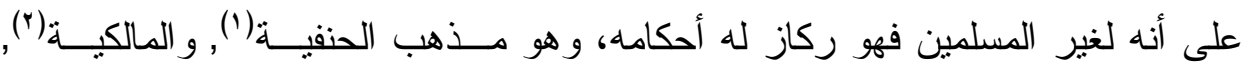

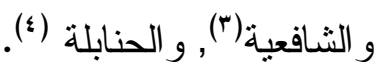
الأدلة على المسألة: المانة

اــ أن الأصل فيما وجد عليه علامة المسلمين أنه ملك مسلم لم يعلم زو الهه عنه.(0)

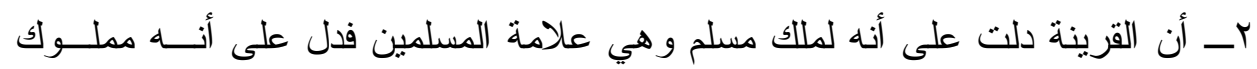
لمسلم، وكذلك دلت على أنه لغير المسلمين بالعلامة فيعمل بهذه القرينة. مسألة: إن كان على المدفون علامتان علامة المسلمين و علامة الكفار :

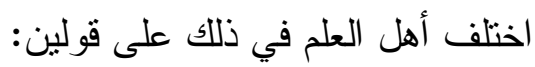

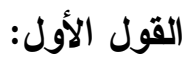

أن له حكم الركاز و هو مذهب المالكية (`).

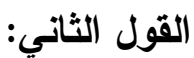
أن له حكم اللقطة وهو مذهب الحنابلة (v). دليل القول الأول: - اله

أن الغالب في الدفن أن يكون دفناً جاهلياً (^).

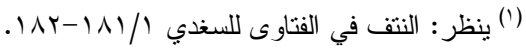

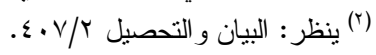

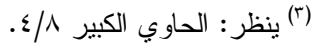

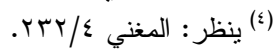

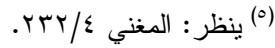

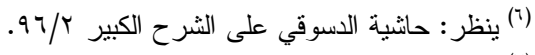

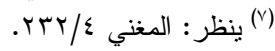

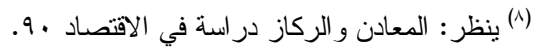




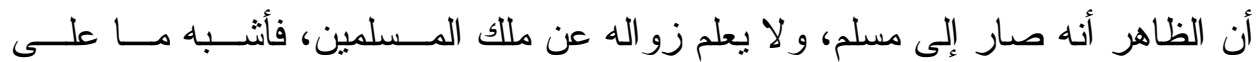
جميعه علامة المسلمين. (') الترجيح:

الظاهر و الله أعلم التقصيل في المسألة فإن كانت البلاد بلاد إسلام قديمة فقول الحنابلـــة قوي لأن الدفن قد يكون في وقت الإسـلام لقدمه، و إما إن كانت البلاد حديثــة الإســلام

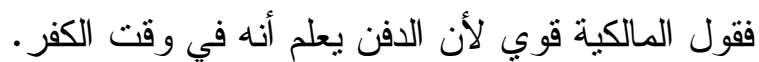
مسألة: إن كان المدفون خاليا من العلامة و لا يعلم هل هو من دفـن الجاهليــة أو مــن دفــن

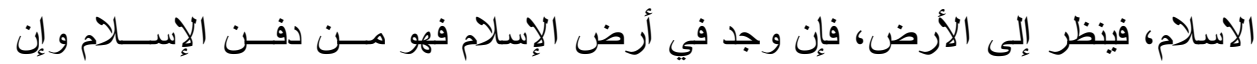

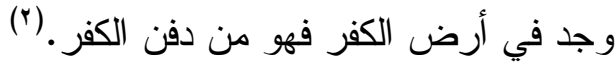


المبحث السادس

جواز دفع اللقطة لو اصفها لقرينة الوصف.

وفيه مطلبان:

المطلب الأول: صورة المسألة. المطلب الثاني: أقو ال أهل العلم في المسألة. المطلب الأول: صورة المسألة:

ذكر ابن فرحون - رحمه الله - هذه المسألة في الباب السبعين من الجزء التـاني مــن التهن

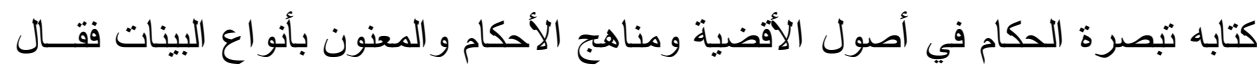

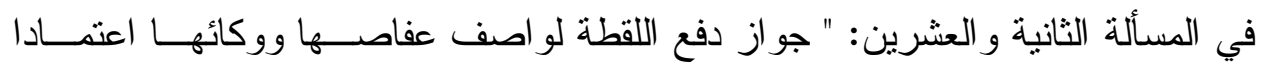

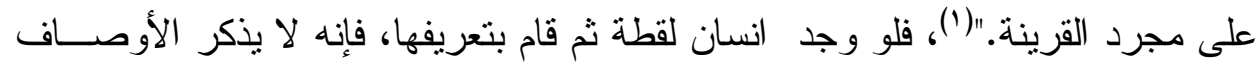

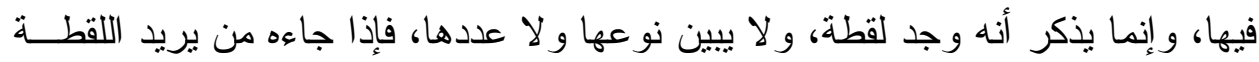

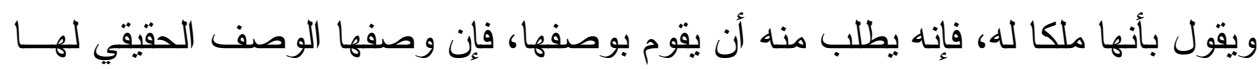

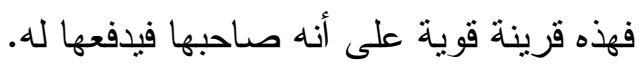
المطلب الثاني: أقو ال أهل العلم في المسألة:

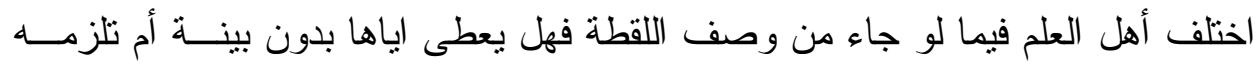

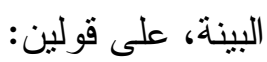

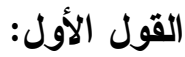
لا يلزم اللاقط الدفع للواصف إلا بيينة، ويجوز أن يدفعها بمجرد الوصف إن غلب على النى

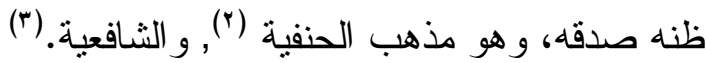

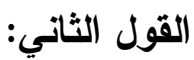

تدفع للواصف بمجرد الوصف و لا يلزم البينة، وهو مذهب المالكية (؛), و الحنابلة.(0) 


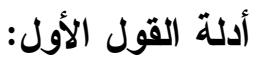

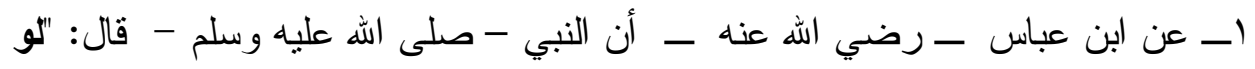

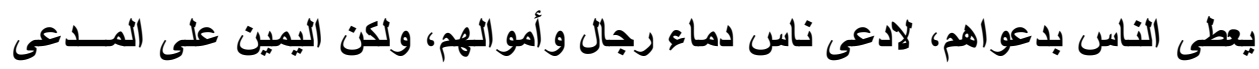

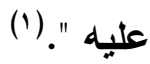

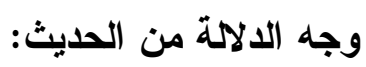

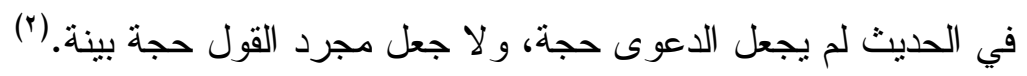

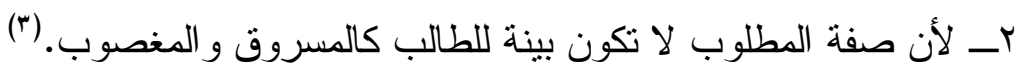

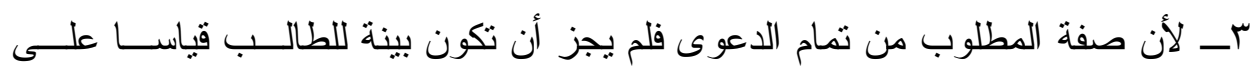
الطلب. (₹)

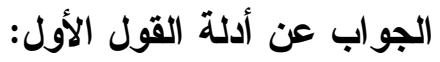
يجاب عن أدلتهم بما ذكره ابن قدامة - رحمه الله - بقوله: " وقول النبي - صــلى الله

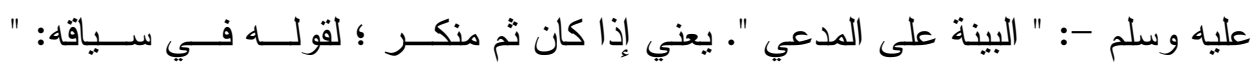

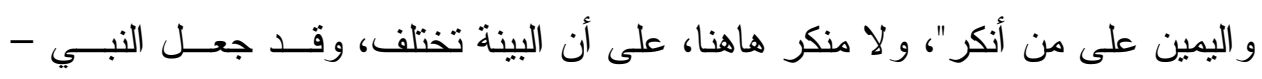

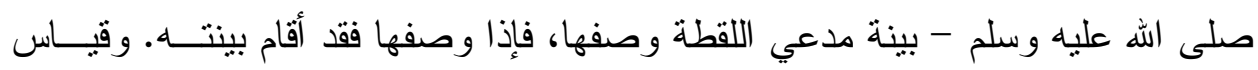

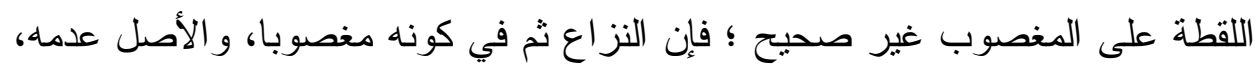

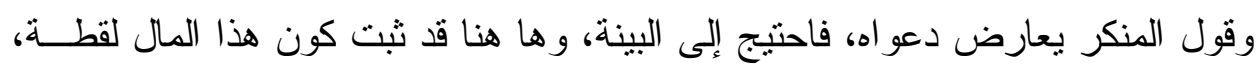

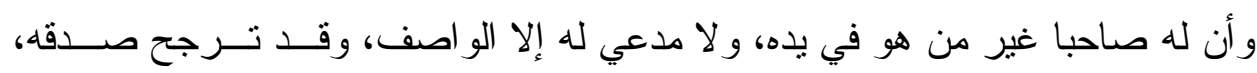

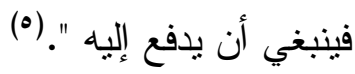

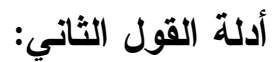

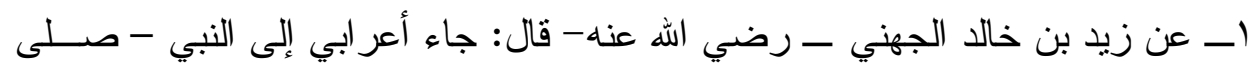

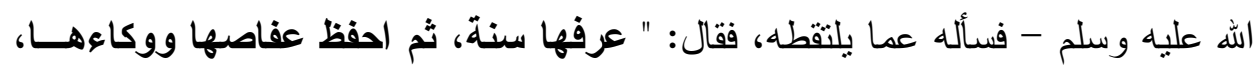

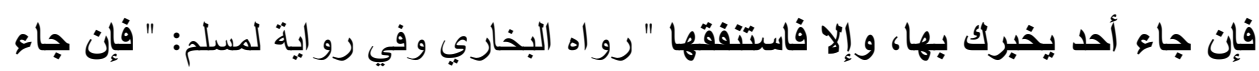

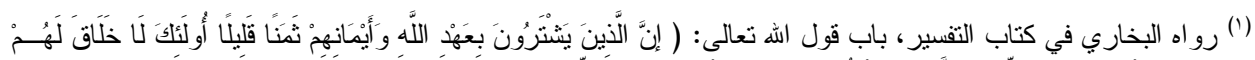

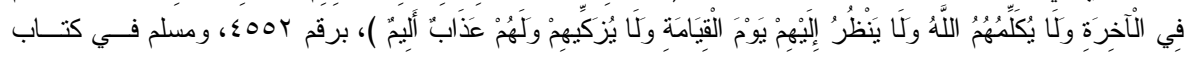

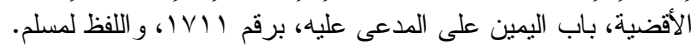

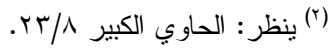

$$
\begin{aligned}
& \text { (r) المرجع السابق. } \\
& \text { () المرجع السابق. }
\end{aligned}
$$

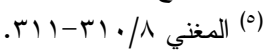


صاحبها فعرف عفاصها، وعددها ووكاءها، فأعطها إياه، وإلا فهي لك "(') وفي حديث أبي بن كعب- رضي الله عنه -: " فإن جاء أحد يخبرك بعددها ووعائهـــا ووكائهـــا. فأعطها إياه "(r). وجه الالالة من الحديثين: في الحديثين دلالة على أنه إذا جاء بوصفها و عرف الهاله عددها ووكاءها فتدفع إليه بمجـرد

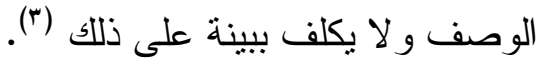

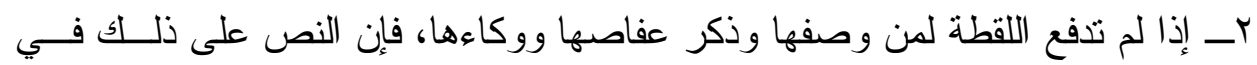

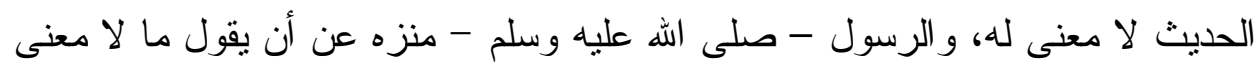

(๕)

rــ إذا كانت البينة لا بد من إحضار ها في اللقطة ولم تذكر في أحاديث اللقطة ؛ فهــذا

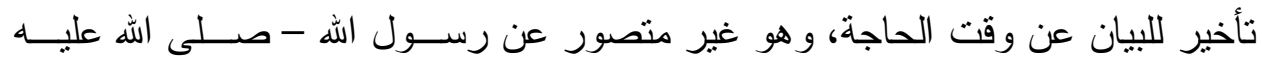
(0). - وسلم

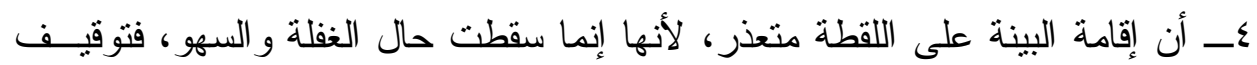

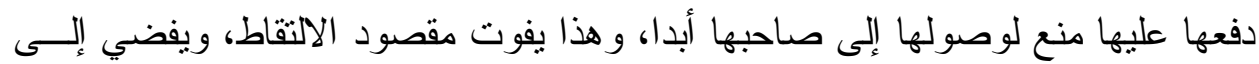

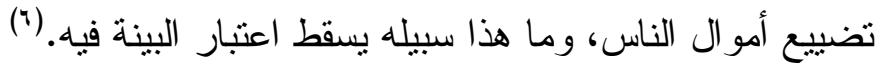

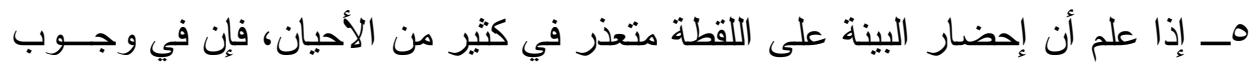

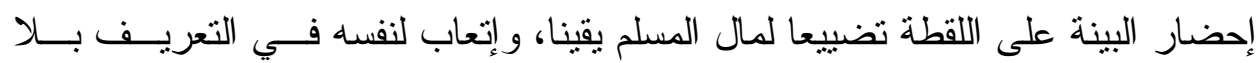
فائدة.

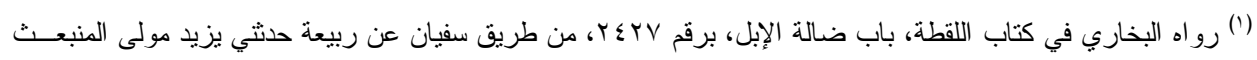

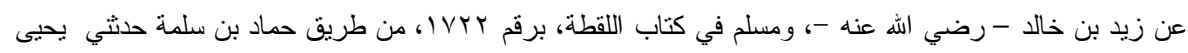

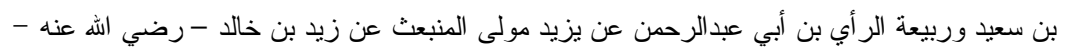

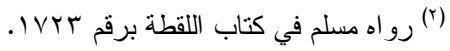

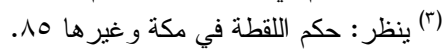

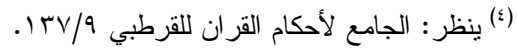

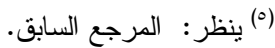

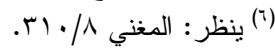

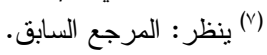


بالتأمل في أدلة الفريقين يترجح القول الثاني القائل بأن اللقطة تدفع للو اصف و لا تلــزم

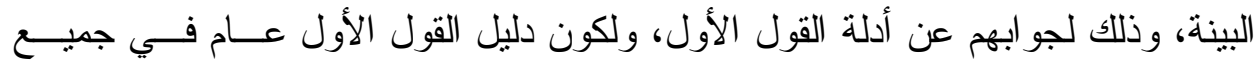

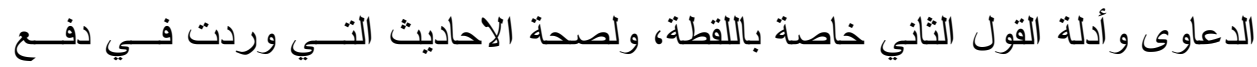
اللقطة لو اصفها، وهي نص في المسألة، فيترجح مذهب المالكية و الحنابلة، و الله أعلم. 


\section{المبحث السابع}

\section{إذا صيدَ صيدّ فلا يملكه واجده إذا كان فيه قرينة}

تدل على أنه مملوكاً لغيره.

وفيه مطلبان:

المطلب الأول: صورة المسألة.

المطلب الثاني: أقوال أهل العلم في المسألة. المطلب الأول: صورة المسألة:

ذكر ابن فرحون - رحمه الله - هذه المسألة في الباب السبعين من الجزء الثـاني مــن الأن

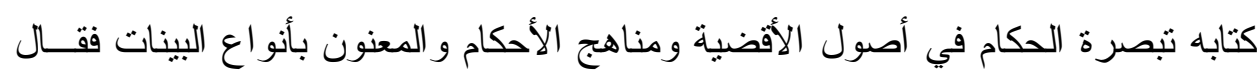

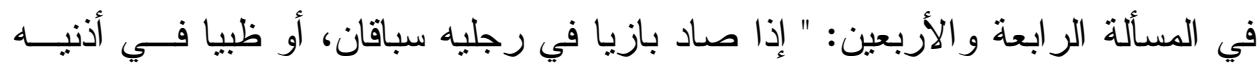

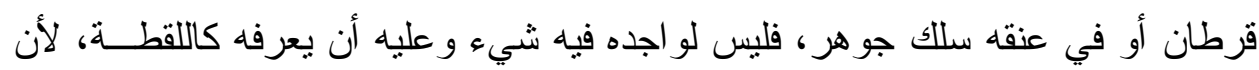

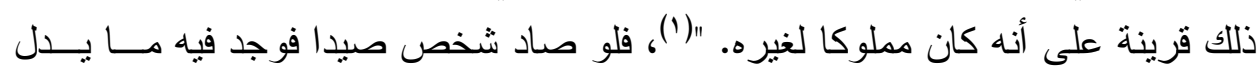

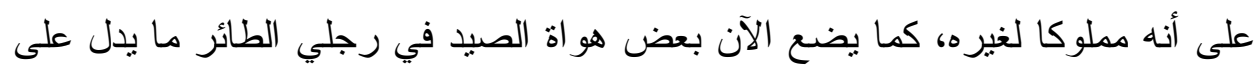

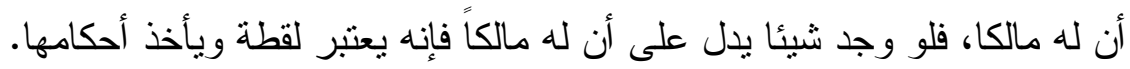
المطلب الثاني: أقو ال أهل العلم في المسألة:

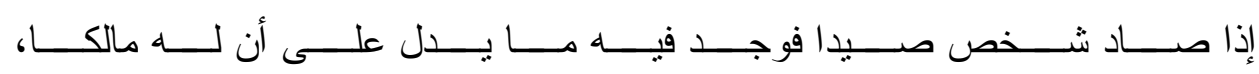

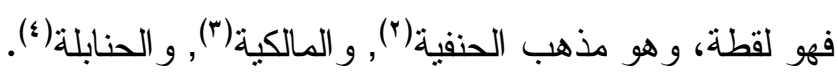
الأدلة على المسألة:

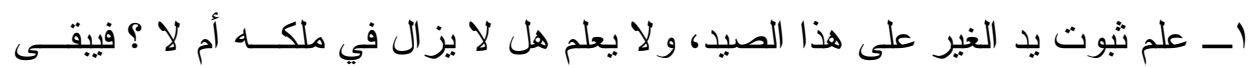
على الأصل وهو أنه ملكا للأول. r-ـ دلت القرينة على أن له ماكل غلها غير الصائد، فيعمل بها.

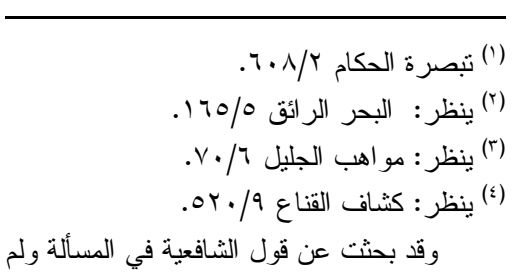

وقد بحثت عن قول الثافعية في المسألة ولم أجد لهم قو لا فيها، بعد البحث في مظانها في بعض كتهم. 
المسائل التي حكم فيها بالقر ائز والأمارات عند ابن فرحون... دكتور/ مطلق بن رجاء بن محمد

بــ لا يتصور أن يكون على الصبد علامة تدل على ملك الغير له من غير أن تكــون

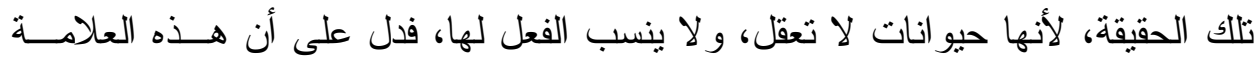
كانت بفعل إنسان و هو المالك لها. 


\section{الخاتمة}

الحمد لله وحده، و الصلاة و السلام على رسوله و عبده، و على آله وصحبه، أما بعد:

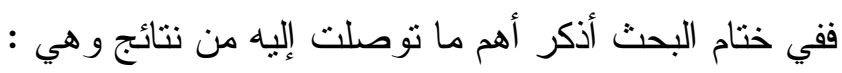
1-أن القر ائن تتتوع باعتبار مصدر ها إلى: قر ائن نصية، وفقهية وقضائية أنية.

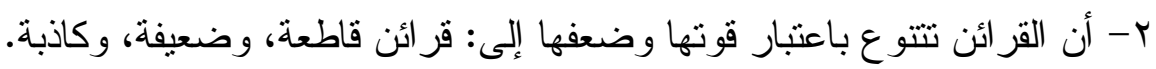

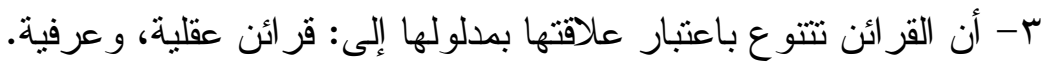
ع - أن القرائن في القانون على نوعين: قر ائن قانونية، وقر ائن قضائن عائية. 0- اتفقت كلمة المذاهب الأربعة على إباحة أخذ اليسير من اللقطة. צ- اتفق العلماء على جو از أخذ ما يبقى من الثمار في الحو ائط ونحوها.

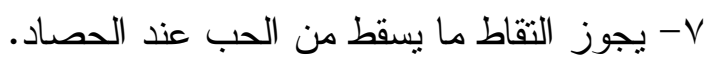

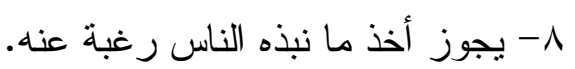

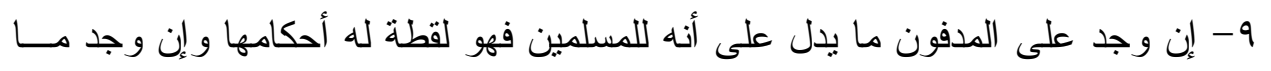
يدل على أنه لغير المسلمين فهو ركاز لله أحكامه. • 1 - اللقطة تدفع لو اصفها ولا تلزم البينة.

1 ا إذا صاد شخص صيدا فوجد فيه ما يدل على أن له مالكا، فهو لقطة. وصلى الله وسلم على رسول الله . 